\title{
The post-monsoon carbon biogeochemistry of the Hooghly-Sundarbans estuarine system under different levels of anthropogenic impacts
}

\author{
Manab Kumar Dutta ${ }^{1}$, Sanjeev Kumar ${ }^{1}$, Rupa Mukherjee ${ }^{1}$, Prasun Sanyal ${ }^{2}$, and Sandip Kumar Mukhopadhyay ${ }^{2}$ \\ ${ }^{1}$ Geosciences Division, Physical Research Laboratory, Ahmedabad - 380009, Gujarat, India \\ ${ }^{2}$ Department of Marine Science, University of Calcutta, Kolkata - 700019, West Bengal, India
}

Correspondence: Sanjeev Kumar (sanjeev@prl.res.in)

Received: 29 June 2018 - Discussion started: 9 July 2018

Revised: 18 December 2018 - Accepted: 2 January 2019 - Published: 22 January 2019

\begin{abstract}
The present study focused on understanding differences in the post-monsoon carbon (C) biogeochemistry of two adjacent estuaries undergoing different levels of anthropogenic stresses by investigating anthropogenically influenced Hooghly estuary and mangrove-dominated estuaries of the Sundarbans in the north-eastern India. The salinity of well-oxygenated estuaries of the Sundarbans (DO: $91 \%-$ $104 \%$ ) varied over a narrow range (12.74-16.69) relative to the Hooghly estuary (0.04-10.37). A mixing model suggested a combination of processes including freshwater intrusion, carbonate precipitation and carbonate dissolution to be a major factor controlling dissolved inorganic C (DIC) dynamics in the freshwater regime of the Hooghly, whereas phytoplankton productivity and $\mathrm{CO}_{2}$ outgassing dominated in the mixing regime. In the Sundarbans, the removal of DIC (via $\mathrm{CO}_{2}$ outgassing, phytoplankton uptake and export to the adjoining continental shelf region) dominated its addition through mineralization of mangrove-derived organic C. The concentration of dissolved organic C (DOC) in the Hooghly was $\sim 40 \%$ higher than in the Sundarbans, which was largely due to the cumulative effect of anthropogenic inputs, DOC-POC interconversion and groundwater contribution rather than freshwater-mediated input. The measured $\delta^{13} \mathrm{C}_{\mathrm{POC}}$ in the Hooghly suggested particulate organic matter contributions from different sources (freshwater runoff, terrestrial $\mathrm{C}_{3}$ plants and anthropogenic discharge), whereas the contribution from $\mathrm{C}_{3}$ plants was dominant at the Sundarbans. The significant departure of $\delta^{13} \mathrm{C}_{\mathrm{POC}}$ from typical mangrove $\delta^{13} \mathrm{C}$ in the mangrove-dominated Sundarbans suggested significant particulate organic $\mathrm{C}$ (POC) modification due to degradation by respiration. The average $p \mathrm{CO}_{2}$ in the
\end{abstract}

Hooghly was higher by $\sim 1291 \mu$ atm compared to the Sundarbans with surface runoff and organic matter degradation by respiration as dominant factors controlling $p \mathrm{CO}_{2}$ in the Hooghly and Sundarbans, respectively. The entire HooghlySundarbans system acted as a source of $\mathrm{CO}_{2}$ to the regional atmosphere with $\sim 17$ times higher emission from the Hooghly compared to the Sundarbans. Taken together, the cycling of $\mathrm{C}$ in estuaries with different levels of anthropogenic influences is evidently different, with significantly higher $\mathrm{CO}_{2}$ emission from the anthropogenically influenced estuary than the mangrove-dominated ones.

\section{Introduction}

Situated at the interface of land and sea, estuaries are highly susceptible to anthropogenic inputs and undergo intricate biogeochemical and hydrological processes. Estuaries play an important role in modulating the global carbon $(\mathrm{C})$ cycle and the anthropogenic carbon dioxide $\left(\mathrm{CO}_{2}\right)$ budget (Bauer et al., 2013; Regnier et al., 2013; Le Quéré et al., 2016). Atmospheric $\mathrm{CO}_{2}$ is sequestered into terrestrial systems through photosynthesis and weathering reactions and is transported to the ocean via rivers and estuaries. Tropical rivers, which constitute $\sim 66 \%$ of global river water discharge, deliver $\sim 0.53 \mathrm{Pg} \mathrm{C}$ to the estuaries annually (Huang et al., 2012). The majority of this exported $\mathrm{C}$ is in dissolved form (dissolved inorganic $\mathrm{C}$ (DIC): $0.21 \mathrm{Pg} \mathrm{Cyr}^{-1}$ and dissolved organic C (DOC): $0.14 \mathrm{Pg} \mathrm{C} \mathrm{yr}^{-1}$ ) with some contribution as particulate (par- 
ticulate organic $\mathrm{C}$ (POC): $0.13 \mathrm{Pg} \mathrm{Cyr}^{-1}$ and particulate inorganic C (PIC): $0.05 \mathrm{Pg} \mathrm{C} \mathrm{yr}^{-1}$ ) (Huang et al., 2012). Although estuaries are only $\sim 4 \%$ of the continental shelf regions, $\mathrm{CO}_{2}$ emission flux from estuarine surface waters is as high as $\mathrm{CO}_{2}$ uptake in continental shelf regions of the world, albeit with large uncertainty (Borges et al., 2005; Chen and Borges, 2009; Cai et al., 2006; Cai, 2011). This suggests estuaries are not only active pathways for transport of C (Ittekkot and Laane, 1991) but also hotspots for biogeochemical modification of labile organic matter (OM) (Frankignoulle et al., 1998).

Mangroves covering $137760 \mathrm{~km}^{2}$ along tropical and subtropical estuaries and coastlines (Giri et al., 2011) are among the most productive natural ecosystems in the world with net primary productivity of $218 \pm 72 \mathrm{Tg} \mathrm{Cyr}^{-1}$ (Bouillon et al., 2008). Fine-root production coupled with litter fall and wood production are primary sources of mangrove-derived C to intertidal forest sediment (Bouillon et al., 2008). The fate of this mangrove-derived $\mathrm{C}$ remains poorly understood. Despite taking $\mathrm{C}$ burial and $\mathrm{CO}_{2}$ emission flux across mangrove sediment-atmosphere interface into account, estimates of global mangrove $\mathrm{C}$ budget showed a significant imbalance between mangrove net primary productivity and its sinks (Bouillon et al., 2008). Earlier studies reported mangroves to be responsible for $\sim 10 \%$ of the global terrestrial derived POC and DOC exports to the coastal zones (Jennerjahn and Ittekkot, 2002; Dittmar et al., 2006). However, recent studies proposed DIC exchange as a major $\mathrm{C}$ export pathway from mangrove forests, which was $\sim 70 \%$ of the total mineralized $\mathrm{C}$ transport from mangrove forests to coastal waters (Maher et al., 2013; Alongi, 2014; Alongi and Mukhopadhyay, 2014). Another study reported groundwater advection from mangroves to be responsible for $93 \%-99 \%$ and $89 \%-92 \%$ of total DIC and DOC exports to the coastal ocean (Maher et al., 2013). Upon extrapolating these $\mathrm{C}$ exports to the global mangrove area, it was found that the calculated $\mathrm{C}$ exports were similar to the missing mangrove $\mathrm{C}$ sink (Sippo et al., 2016). The remaining $C$ that escapes export gets buried in subsurface sediment layers and participates either in complex anaerobic processes (linked to production of biogenic trace gases like $\mathrm{CH}_{4}$ ) or undergoes long-term sequestration (Jennerjhan and Ittekkot, 2002; Barnes et al., 2006; Kristensen and Alongi, 2006; Donato et al., 2011; Linto et al., 2014).

Apart from lateral transport of dissolved and particulate $\mathrm{C}$, biogeochemical processes such as primary production, OM mineralization, carbonate precipitation / dissolution and water-atmosphere $\mathrm{CO}_{2}$ exchange occurring in the estuary also regulate the inorganic and organic $\mathrm{C}$ biogeochemistry of a mangrove-dominated estuary. These processes largely depend upon $\mathrm{pH}$, nutrient availability and euphotic depth variability, as well as planktonic and bacterial biodiversity and community compositions. The biogeochemical cycling of bioavailable elements, such as $\mathrm{C}$ and $\mathrm{N}$, in a mangrovedominated estuary is largely different from anthropogenically polluted estuary, where much of the $\mathrm{OM}$ is derived from domestic, agricultural and industrial waste. In anthropogenically affected estuarine systems, heterotrophy generally dominates over autotrophy (Heip et al., 1995; Gattuso et al., 1998) and a substantial fraction of biologically reactive OM gets mineralized within the system (Servais et al., 1987; Ittekkot, 1988; Hopkinson et al., 1997; Moran et al., 1999). However, this is not always the case, as observed in the Guanabara Bay, Brazil, which acts as a strong $\mathrm{CO}_{2}$ sink enhanced by eutrophication (Cotovicz Jr. et al., 2015). The lack of ample rate measurements of the above-mentioned biogeochemical processes in many regions of the world restrains biogeochemists from an in-depth understanding of these processes in different ecological settings. It also leads to an uncertainty in the estimation of a coastal $\mathrm{C}$ budget on a global scale.

In India, research related to $\mathrm{C}$ biogeochemistry of estuarine ecosystems has been in focus since last two decades with an emphasis on estuaries located in southern India (e.g. Bouillon et al., 2003; Sarma et al., 2012, 2014; Bhavya et al., 2017, 2018). The estuaries located in the northern part of India have received limited attention, including the adjacently located Hooghly estuary and the estuaries of the Sundarbans, which are part of the Ganga-Brahmaputra river system (Fig. 1). Characteristically, the Hooghly and the estuaries of the Sundarbans are different from each other. The Hooghly estuary experiences significantly higher anthropogenic influence compared to the mangrove-dominated Sundarbans as evidenced by high nutrient and freshwater inputs (Table 1). The anthropogenic influences largely include a supply of the industrial effluents and domestic sewage on a daily basis from industries and major cities (Kolkata and Howrah) located upstream (Table 1). The industries along the Hooghly are principally jute (Corchorus olitorius)-based, which produce fabrics for packaging a wide range of agricultural and industrial commodities.

Earlier, the major focus of biogeochemical studies in the Hooghly and the estuaries of the Sundarbans had been on the biogeochemistry of trace gases (Mukhopadhyay et al., 2002; Biswas et al., 2004, 2007; Ganguly et al., 2008, 2009; Dutta et al., 2013, 2015, 2017) with the exception of one comprehensive study on nutrient budgets at the Hooghly estuary (Mukhopadhyay et al., 2006). Recently, attempts have been made to understand different aspects of $\mathrm{C}$ cycling in these two estuaries (Samanta et al., 2015; Ray et al., 2015, 2018; Akhand et al., 2016). Samanta et al. (2015) comprehensively studied DIC dynamics in the Hooghly estuary, whereas Akhand et al. (2016) focused on DIC and $p \mathrm{CO}_{2}$ at the HooghlyMatla estuary. Different aspects of C cycling in the HooghlySundarbans system have been reported by Ray et al. (2015, 2018). Barring Samanta et al. (2015), which has wider spatial and temporal coverages with respect to DIC in the Hooghly, other studies are severely limited in spatial coverage with focus on the middle to lower parts of the Hooghly estuary and a few locations in the Sundarbans (one location by Ray et al., 2015, 2018; three locations by Akhand et al., 2016). Given the vast expanse of these estuaries, the extrapolation of data 
Table 1. General characteristics of the Hooghly estuary and the estuaries of the Sundarbans.

\begin{tabular}{|c|c|c|}
\hline Parameters & Hooghly & Sundarbans \\
\hline $\begin{array}{l}\text { Nutrients } \\
\text { (post-monsoon) }\end{array}$ & $\begin{array}{l}\text { DIN: } 14.72 \pm 1.77 \text { to } 27.20 \pm 2.05 \mu \mathrm{M} \\
\text { DIP: } 1.64 \pm 0.23 \text { to } 2.11 \pm 0.46 \mu \mathrm{M} \\
\text { DSi: } 77.75 \pm 6.57 \text { to } 117.38 \pm 11.54 \mu \mathrm{M} \\
\text { Mukhopadhyay et al. }(2006)\end{array}$ & $\begin{array}{l}\text { DIN: } 11.70 \pm 7.65 \mu \mathrm{M} \\
\text { DIP: } 1.01 \pm 0.52 \mu \mathrm{M} \\
\text { DSi: } 75.9 \pm 36.9 \mu \mathrm{M} \\
\text { Biswas et al. }(2004)\end{array}$ \\
\hline $\begin{array}{l}\text { Chl } a \\
\text { (post-monsoon) }\end{array}$ & $\begin{array}{l}2.35-2.79 \mathrm{mg} \mathrm{m}^{-3} \\
\text { Mukhopadhyay et al. (2006) }\end{array}$ & $\begin{array}{l}7.88 \pm 1.90 \mathrm{mg} \mathrm{m}^{-3} \\
\text { Dutta et al. }(2015)\end{array}$ \\
\hline Population density & $\begin{array}{l}\text { North } 24 \text { Parganas and Hooghly: } 2500 \mathrm{~km}^{-2} \text {, } \\
\text { Kolkata: } 22000 \mathrm{~km}^{-2} \text {, Howrah: } 3300 \mathrm{~km}^{-2} \text {, } \\
\text { South } 24 \text { Parganas: } 820 \mathrm{~km}^{-2}\end{array}$ & No major cities and towns \\
\hline $\begin{array}{l}\text { Freshwater discharge } \\
\text { (post-monsoon) }\end{array}$ & $\begin{array}{l}\text { 3070-7301 million } \mathrm{m}^{3} \\
\text { Rudra et al. (2014) }\end{array}$ & No information available \\
\hline Catchment area & $\begin{array}{l}6 \times 10^{4} \mathrm{~km}^{2} \\
\text { Sarkar et al. (2017) }\end{array}$ & No information available \\
\hline $\begin{array}{l}\text { Industrial and munici- } \\
\text { pal } \\
\text { waste-water discharge }\end{array}$ & $\begin{array}{l}1153.8 \text { million } \mathrm{Ld}^{-1} \\
\text { Ghosh, (1973), Khan (1995) }\end{array}$ & No information available \\
\hline Dissolved metal flux & $\begin{array}{l}\text { Increased from } 230 \% \text { to } 1770 \% \text { annually } \\
\text { Samanta and Dalai (2018) }\end{array}$ & No information available \\
\hline
\end{tabular}

from these studies for the entire ecosystem may lead to overestimation and underestimation.

The primary objective of the present study was to understand differences in varied aspects of the $\mathrm{C}$ cycle (DIC, DOC, POC and $\mathrm{CO}_{2}$ ) of the Hooghly and the estuaries of the Sundarbans during the post-monsoon season with relatively better spatial coverage compared to previous studies. The post-monsoon sampling was chosen because of relatively stable estuarine conditions for wider spatial coverage and peak mangrove leaf litter fall during this season (Ray et al., 2011), which may have an influence on estuarine $\mathrm{C}$ dynamics. Considering the different natures and quantities of supplied $\mathrm{OM}$ within these two contrasting systems, we hypothesized C metabolism in these two estuaries to be very different with higher $\mathrm{CO}_{2}$ exchange flux from anthropogenically influenced estuary compared to the mangrove-dominated one. Specifically, the major aims of the present study were to investigate (a) factors controlling DIC and DOC dynamics in the region, (b) the sources and fate of POC in these two contrasting systems, and (c) the partial pressure of $\mathrm{CO}_{2}\left(p \mathrm{CO}_{2}\right)$ and its controlling mechanisms along with exchange across the wateratmosphere interface at the Hooghly-Sundarbans during the post-monsoon period.

\section{Materials and methods}

\subsection{Study area}

The present study was carried out in the mangrove dominated estuaries of the Indian Sundarbans and anthropogenically dominated Hooghly estuary in northeastern India. The Sundarbans $\left(21^{\circ} 32^{\prime}\right.$ and $22^{\circ} 40^{\prime} \mathrm{N}: 88^{\circ} 05^{\prime}$ and $89^{\circ}$ E, Fig. 1a), inscribed as a UNESCO world heritage site, is the largest mangrove forest in the world situated at the land-ocean boundary of the Ganges-Brahmaputra delta and the Bay of Bengal (BOB). Out of the $10200 \mathrm{~km}^{2}$ area of the Sundarbans, $41 \%$ is in India and the rest is in Bangladesh. The Indian part of Sundarbans (or Sundarbans Biosphere Reserve) contains $4200 \mathrm{~km}^{2}$ of mangrove reserve forest and $1800 \mathrm{~km}^{2}$ of estuarine waterways along with reclaimed areas. The Sundarbans is crisscrossed by several rivers, such as Muriganga, Saptamukhi, Thakuran, Matla, Bidya, Gosaba and Haribhanga, forming a sprawling archipelago of 102 islands covered with thick mangroves mostly composed of Avicennia alba, Avicennia marina and Avicennia officinalis. A semidiurnal tide with a mean depth $\sim 6 \mathrm{~m}$ is a general characteristic of the estuary (Dutta et al., 2015).

The second study site, the Hooghly estuary $\left(21^{\circ} 31^{\prime}-\right.$ $23^{\circ} 20^{\prime} \mathrm{N}$ and $87^{\circ} 45^{\prime}-88^{\circ} 45^{\prime} \mathrm{E}$ ), is the first deltaic offshoot of the Ganges, which ultimately mixes with the northern BOB. Like the estuaries of the Sundarbans, tides are semidiurnal in nature in the Hooghly with variable depth along the channel $(\sim 21 \mathrm{~m}$ at Diamond Harbour (H6) to $\sim 8 \mathrm{~m}$ 

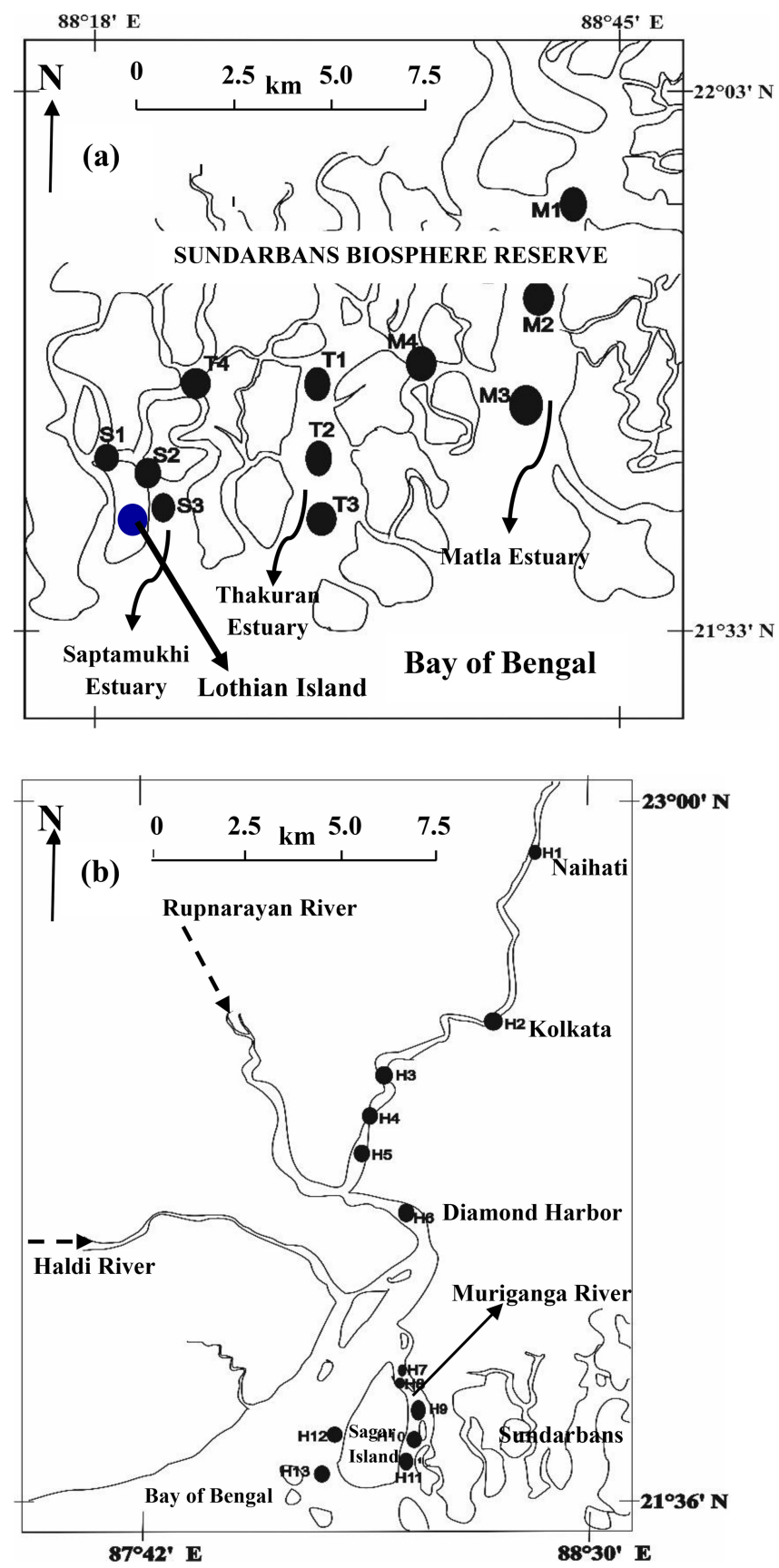

Figure 1. Sampling locations at the (a) estuaries of the Sundarbans and (b) Hooghly estuary.

at the mouth of the estuary; Fig. 1b) (CIFRI, 2012). Before mixing with the $\mathrm{BOB}$, the lower estuarine part of the Hooghly divides into two channels, one being a main estuarine stream, which directly mixes with the BOB and another smaller channel known as Muriganga (mean depth $\sim 6 \mathrm{~m}$; Sadhuram et al., 2005). The width of the river at the mouth of the estuary is $\sim 25 \mathrm{~km}$ (Mukhopadhyay et al., 2006). Both estuarine systems experience a typical tropical climate with three distinct seasons: pre-monsoon (February-May), monsoon (June-September) and post-monsoon (OctoberJanuary) with $\sim 80 \%$ rainfall during monsoon.

Covering upper, middle and lower estuarine regions, the present study was carried out during low-tide conditions in three major estuaries of the Indian Sundarbans (Saptamukhi (S1-S3), Thakuran (T1-T3) and Matla (M1-M3); Fig. 1a) along with its related waterways (S4 and M4). The low-tide post-monsoon sampling was preferred as it was the ideal time to evaluate the effect of mangroves on the adjoining estuary due to peak mangrove leaf litter fall (Ray et al., 2011) and groundwater (or porewater) discharge. To compare and bring out the contrast in different components of the $\mathrm{C}$ cycle between mangrove-dominated and anthropogenically influenced estuaries, low-tide sampling was also performed at 13 locations (H1-H13, Fig. 1b) in the Hooghly estuary (stretch: $\sim 150 \mathrm{~km}$ ).

For the purpose of discussion, henceforth, both the estuarine systems will be described as the "Hooghly-Sundarbans system" and the estuaries of the Sundarbans will be called the "Sundarbans" unless discussed individually.

\subsection{Sampling and experimental techniques}

During the post-monsoon season (November 2016), estuarine surface water samples were collected in duplicate at different locations of the Hooghly-Sundarbans system using a Niskin bottle (Oceantest equipment; capacity: 5L). A brief description of the on and off field sampling and experimental techniques used during the present study are described below.

\subsubsection{Sample collection and on board measurements}

Water temperature and $\mathrm{pH}$ of the collected samples were measured on board using a thermometer $\left( \pm 0.1^{\circ} \mathrm{C}\right)$ and portable $\mathrm{pH}$ meter (Orion Star A211) fitted with a Ross-type combination electrode calibrated (as described by Frankignoulle and Borges, 2001) on the NBS scale (reproducibility: $\pm 0.005 \mathrm{pH}$ units). Salinity $( \pm 0.1)$ and dissolved oxygen (DO: $\pm 0.1 \mathrm{mg} \mathrm{L}^{-1}$ ) concentrations were measured on board following the Mohr-Knudsen and Winkler titration methods, respectively (Grasshoff et al., 1983). For total alkalinity (TAlk), $50 \mathrm{~mL}$ of filtered (Whatman GF/F filter) estuarine water was titrated on board in a closed cell using $0.1 \mathrm{~N} \mathrm{HCl}$ following the potentiometric titration method (Bouillon et al., 2003). Uncertainty in TAlk measurements was $\pm 1 \mu \mathrm{mol} \mathrm{kg} \mathrm{kg}^{-1}$ as estimated using certified reference material (Dickson standard: CRM-131-0215).

For DIC and $\delta^{13} \mathrm{C}_{\text {DIC }}$ measurements, estuarine surface waters were collected by gently overfilling glass vials fitted with Teflon septa (Fig. 1). Porewater was also collected from the lower littoral zone of the Lothian Island (one of the virgin islands of the Indian Sundarbans, Fig. 1a) by digging a hole ( $\sim 30 \mathrm{~cm}$ below the water table). It was not possible to collect porewater samples from the middle and upper littoral zones 
of the island due to logistic problems. After purging water at least twice in the bore, the sample was collected from the bottom of the bore through a syringe and transferred to the glass vial (Maher et al., 2013). Twelve groundwater samples were collected from the nearby locations of the HooghlySundarbans system via tube pump. After collection, all samples for DIC and $\delta^{13} \mathrm{C}_{\text {DIC }}$ were preserved immediately by adding a saturated $\mathrm{HgCl}_{2}$ solution to arrest the microbial activity.

For both DOC and SPM (suspended particulate matter) measurements, surface water samples were filtered on board through pre-weighted and pre-combusted $\left(500^{\circ} \mathrm{C}\right.$ for $6 \mathrm{~h}$ ) Whatman GF/F filters (pore size: $0.7 \mu \mathrm{m}$ ). Filtrates were kept for DOC analysis in brown bottles followed by immediate preservation via addition of $\mathrm{H}_{3} \mathrm{PO}_{4}(50 \mu \mathrm{L} / 15 \mathrm{~mL}$ sample) (Bouillon et al., 2003), whereas the residues were kept for particulate matter analysis. Collected DIC, DOC and SPM samples were properly preserved at $4{ }^{\circ} \mathrm{C}$ during transportation to the laboratory. Additionally, micrometeorological parameters associated with the water-atmosphere $\mathrm{CO}_{2}$ exchange flux computation continuously monitored at $10 \mathrm{~m}$ height over the estuary using a portable weather monitor (DAVIS - Vantage Pro2 Plus).

\subsubsection{Laboratory measurements}

The DIC concentrations were measured using Coulometer (model: UIC. Inc. CM - 5130) with an analytical uncertainty of $\pm 0.8 \%$. The $\delta^{13} \mathrm{C}_{\text {DIC }}$ were measured using GasBench II attached to a continuous flow mass spectrometer (Thermo Scientific MAT 253) with precision better than $0.10 \%$. The DOC was measured using a high-temperature catalytic oxidation analyzer (Shimadzu-TOC-L CPH), which was calibrated using a potassium hydrogen phthalate (KHP) solution containing 1, 2, 5, 10 and $20 \mathrm{mg} \mathrm{L}^{-1}$ of DOC (Ray et al., 2018). The analytical error for DOC measurement was $<2 \%$. For SPM measurements, filter paper containing SPM was dried in hot-air oven at $60^{\circ} \mathrm{C}$ and final weights were noted. The SPM were calculated based on differences between final and initial weights of the filter paper and volumes of water filtered. For measurements of POC and $\delta^{13} \mathrm{C}_{\mathrm{POC}}$, filter papers containing SPM were decarbonated (by $\mathrm{HCl}$ fumes) and analysed using an Elemental Analyzer (Flash 2000) attached to the continuous flow mass spectrometer (Thermo Scientific MAT 253) via conflo. The $\delta^{13} \mathrm{C}_{\mathrm{POC}}$ values are reported relative to V-PDB with reproducibility better than $\pm 0.10 \%$, whereas uncertainty for POC was $<10 \%$.

\subsubsection{Computation of air-water $\mathrm{CO}_{2}$ flux and \%DO}

The $p \mathrm{CO}_{2}$ were calculated based on surface water temperature, salinity, TAlk, $\mathrm{pH}$ and dissociation constants calculated following Millero (2013). The uncertainty for estimated $p \mathrm{CO}_{2}$ was $\pm 1 \%$. The $\mathrm{CO}_{2}$ exchange fluxes $\left(F \mathrm{CO}_{2}\right.$ in $\mu \mathrm{mol} \mathrm{m}{ }^{-2} \mathrm{~h}^{-1}$ ) across the water-atmosphere boundary of the estuary were calculated as follows:

$F \mathrm{CO}_{2}=k \times K_{\mathrm{H}}^{\mathrm{CO}_{2}} \times\left[p \mathrm{CO}_{2 \text { (water) }}-p \mathrm{CO}_{2 \text { (atmosphere) }}\right]$,

where $K_{\mathrm{H}}^{\mathrm{CO}_{2}}=\mathrm{CO}_{2}$ solubility. $k$ is the gas transfer velocity, which is highly variable and remains a matter of debate (Raymond and Cole, 2001). The $k$ during the present study was computed as a function of wind velocity following the Liss and Merlivat (1986) parametrization. For the same wind velocity, the parametrization of Liss and Merlivat (1986) provides the lowest $k$ value over other parametrization (Wanninkhof, 1992; Raymond and Cole, 2001; Borges et al., 2004) and therefore the $\mathrm{FCO}_{2}$ presented during this study may be considered to be a conservative estimate. The wind-velocity-based $k$ estimation for the Hooghly-Sundarbans system has been applied in earlier studies as well (Mukhopadhyay et al., 2002; Biswas et al., 2004). Mean global atmospheric $\mathrm{CO}_{2}$ mixing ratio in dry air during 2016 (data source: ftp://aftp.cmdl. noaa.gov/products/trends/co2/co2_annmean_gl.txt, last access: 10 May 2018) was corrected for water vapour partial pressure to calculate $p \mathrm{CO}_{2}$ (atmosphere). The fraction, $K_{\mathrm{H}}^{\mathrm{CO}_{2}} \times\left[p \mathrm{CO}_{2 \text { (water) }}-p \mathrm{CO}_{2 \text { (atmosphere) }}\right]$ is the departure of free dissolved $\mathrm{CO}_{2}$ from atmospheric equilibrium that may be termed "excess $\mathrm{CO}_{2}\left(\mathrm{ECO}_{2}\right)$ " (Zhai et al., 2005).

The percent saturation of DO and apparent oxygen utilization (AOU, departure of dissolved $\mathrm{O}_{2}$ from atmospheric equilibrium) were calculated as follows:

$\%$ saturation of $\mathrm{DO}=\left(\left[\mathrm{O}_{2}\right]_{\text {Measured }} \times 100 /\left[\mathrm{O}_{2}\right]_{\text {Equilibrium }}\right)$ $\mathrm{AOU}=\left(\left[\mathrm{O}_{2}\right]_{\text {Equilibrium }}-\left[\mathrm{O}_{2}\right]_{\text {Measured }}\right)$,

where $\left[\mathrm{O}_{2}\right]_{\text {Equilibrium }}$ is the equilibrium DO concentration calculated at in situ temperature and salinity (Weiss, 1970) and $\left[\mathrm{O}_{2}\right]_{\text {Measured }}$ is the measured DO concentration of surface water.

\subsubsection{Mixing model calculation}

Considering salinity as a conservative tracer and an ideal indicator for estuarine mixing mechanism (Fry, 2002), the conservative mixing model was applied to the Hooghly estuary to understand the addition or removal of dissolved and particulate $\mathrm{C}$ by in situ biogeochemical processes. Concentrations and stable isotopic compositions of dissolved or particulate $\mathrm{C}$ (presented as $\mathrm{C}$ ) during conservative mixing $\left(\mathrm{C}_{\mathrm{CM}}\right.$ and $\delta^{13} \mathrm{C}_{\mathrm{CM}}$ ) were computed as follows (Carpenter et al., 1975; Mook and Tan, 1991):

$\mathrm{C}_{\mathrm{CM}}=\mathrm{C}_{\mathrm{F}} F_{\mathrm{F}}+\mathrm{C}_{\mathrm{M}} F_{\mathrm{M}}$

$\delta^{13} \mathrm{C}_{\mathrm{CM}}=\frac{\left\{\begin{array}{c}S_{\mathrm{S}}\left[\mathrm{C}_{\mathrm{F}} \delta^{13} \mathrm{C}_{\mathrm{F}}-\mathrm{C}_{\mathrm{M}} \delta^{13} \mathrm{C}_{\mathrm{M}}\right] \\ +S_{\mathrm{F}} \mathrm{C}_{\mathrm{M}} \delta^{13} \mathrm{C}_{\mathrm{M}}-S_{\mathrm{M}} \mathrm{C}_{\mathrm{F}} \delta^{13} \mathrm{C}_{\mathrm{F}}\end{array}\right\}}{S_{\mathrm{S}}\left(\mathrm{C}_{\mathrm{F}}-\mathrm{C}_{\mathrm{M}}\right)+S_{\mathrm{F}} \mathrm{C}_{\mathrm{M}}-S_{\mathrm{M}} \mathrm{C}_{\mathrm{F}}}$.

Here, $S$ denotes salinity, the suffixes CM, F, M and S denote conservative mixing, freshwater endmember, marine endmember and sample. $F_{\mathrm{F}}$ is freshwater fraction is $1-\left(S_{\mathrm{S}} / S_{\mathrm{M}}\right)$ 
and $F_{\mathrm{M}}=$ marine water fraction is $\left(1-F_{\mathrm{F}}\right)$. $\mathrm{C}_{\text {Sample }}>\mathrm{C}_{\mathrm{CM}}$ indicates $\mathrm{C}$ addition, whereas the reverse indicates removal. For model calculation, means of salinities, $\mathrm{C}$ concentrations and $\delta^{13} \mathrm{C}$ of samples collected at salinity $\leq 0.3$ at the Hooghly estuary were considered to be endmember values for freshwater, whereas respective values for marine endmembers were taken from Dutta et al. (2010) and Akhand et al. (2012). Quantitative deviations ( $\Delta \mathrm{C}$ and $\Delta \delta^{13} \mathrm{C}$ ) of measured $\mathrm{C}$ concentrations and $\delta^{13} \mathrm{C}$ from the respective conservative mixing values were estimated as follows (Alling et al., 2012):

$$
\begin{aligned}
& \Delta \mathrm{C}=\left(\mathrm{C}_{\text {Sample }}-\mathrm{C}_{\mathrm{CM}}\right) / \mathrm{C}_{\mathrm{CM}} \\
& \Delta \delta^{13} \mathrm{C}=\delta^{13} \mathrm{C}_{\text {Sample }}-\delta^{13} \mathrm{C}_{\mathrm{CM}}
\end{aligned}
$$

Plots between $\Delta \mathrm{C}$ and $\Delta \delta^{13} \mathrm{C}$ for DIC and POC have been used to understand processes influencing DIC and POC in the Hooghly-Sundarbans system. However, the above model could not be applied to DOC due to the unavailability of $\delta^{13} \mathrm{C}_{\text {DOC }}$ during the present study.

Unlike the Hooghly, direct application of abovementioned conservative mixing model was not justified for the mangrove-dominated Sundarbans due to the narrow salinity gradient (see later). However, assuming that apart from conservative mixing only mangrove-derived $\mathrm{C}$ ( $\Delta \mathrm{C}_{\text {Mangrove }}$ ) contributes to the estuarine $\mathrm{C}$ pool, an approach can be taken to quantify $\Delta \mathrm{C}_{\text {Mangrove }}$. Two different mass balance equations used by Miyajima et al. (2009) for estimating $\Delta \mathrm{DIC}_{\text {Mangrove }}$ was extended to calculate $\Delta \mathrm{C}_{\text {Mangrove }}$ during the present study:

$$
\begin{aligned}
& \Delta \mathrm{C}_{\text {Mangrove }}\left(\Delta \mathrm{C}_{\mathrm{M} 1}\right)=\mathrm{C}_{\text {Sample }}-\mathrm{C}_{\mathrm{CM}} \\
& \Delta \mathrm{C}_{\text {Mangrove }}\left(\Delta \mathrm{C}_{\mathrm{M} 2}\right)=\frac{\mathrm{C}_{\text {Sample }} \times\left[\delta^{13} \mathrm{C}_{\mathrm{CM}}-\delta^{13} \mathrm{C}_{\text {Sample }}\right]}{\delta^{13} \mathrm{C}_{\mathrm{CM}}-\delta^{13} \mathrm{C}_{\text {Mangrove }}} .
\end{aligned}
$$

For model calculation, $\delta^{13} \mathrm{C}_{\text {Mangrove was taken as }-28.4 \% \text { o }}$ for the Sundarbans (Ray et al., 2015) and endmembers were taken to be the same as the Hooghly, as the estuaries of the Sundarbans are an offshoot of the lower Hooghly estuary.

\subsubsection{Computation of advective DIC input from mangrove forest to estuary}

A first-time baseline value for advective DIC input from mangrove forest sediment to the adjoining estuary ( $\left.F_{\text {DIC }}\right)$ via porewater exchange was calculated following Reay et al. (1995):

$F_{\text {DIC }}=$ sediment porosity $\times$ mean linear velocity $\times$ mean pore water DIC conc.

Mean linear velocity $=$ pore water specific discharge $/$ sediment porosity.

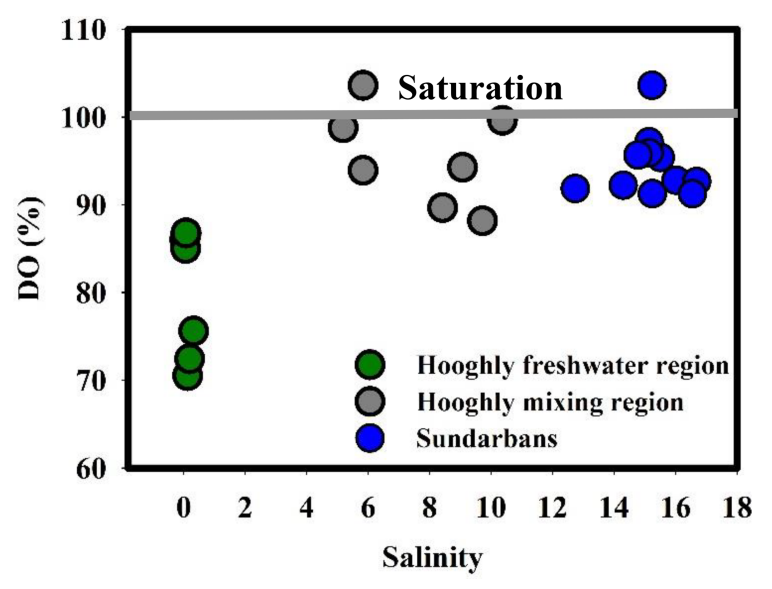

Figure 2. Percent saturation of DO-salinity relationship in the Hooghly-Sundarbans system.

\section{Results}

\subsection{Environmental parameters}

During the present study, the water temperature did not show any distinct spatial trend and varied from 28 to $29^{\circ} \mathrm{C}$ and 30.5 to $33^{\circ} \mathrm{C}$ for the Sundarbans (Table 2) and Hooghly (Table 3$)$. Salinity of the estuaries of the Sundarbans varied over a narrow range (12.74 to 16.69 ; Table 2 ) with a minimum at the upper estuarine locations throughout. A relatively sharp salinity gradient was noticed at the Hooghly estuary $(0.04$ to 10.37 ; Table 3 ). Based on the observed salinity gradient, the Hooghly estuary can be divided into two major salinity regimes: (a) a freshwater regime $(\mathrm{H} 1-\mathrm{H} 6)$ and (b) mixing regime (H7-H13; Fig. 1b). However, due to the narrow salinity range, no such classification was possible for the estuaries of the Sundarbans. The estuaries of the Sundarbans were relatively well-oxygenated (DO $=91 \%$ to $104 \%$ ) compared to the Hooghly estuary ( $\mathrm{DO}=71 \%$ to $104 \%$; Fig. 2). Both $\mathrm{pH}$ and TAlk in the Hooghly estuary (pH: 7.31 to 8.29, TAlk: 1797 to $2862 \mu \mathrm{eq} \mathrm{L}^{-1}$, Table 3 ) showed relatively wider variation compared to the estuaries of the Sundarbans ( $\mathrm{pH}: 8.01$ to 8.13 , TAlk: 2009 to $2289 \mu \mathrm{eq} \mathrm{L}^{-1}$; Table 2).

\subsection{Variability in DIC, $\delta^{13} C_{\text {DIC }}$ and DOC}

In the Sundarbans, both DIC and $\delta^{13} \mathrm{C}_{\text {DIC }}$ varied over a relatively narrow range $(\mathrm{DIC}=1683$ to $1920 \mu \mathrm{M}$, mean: $1756 \pm 73 \mu \mathrm{M} ; \quad \delta^{13} \mathrm{C}_{\mathrm{DIC}}=-5.93 \%$ o to $-4.29 \%$, mean: $-5.04 \pm 0.58 \%$, Table 2 ) compared to the Hooghly estuary (DIC $=1678$ to $2700 \mu \mathrm{M}$, mean: $2083 \pm 320 \mu \mathrm{M} ; \delta^{13} \mathrm{C}_{\mathrm{DIC}}=$ $-8.61 \%$ o to $-5.57 \%$, mean: $-6.95 \pm 0.90 \%$; Table 3$)$. In the Hooghly, DIC was relatively higher in the freshwater regime compared to the mixing regime, whereas reverse was observed for $\delta^{13} C_{\text {DIC }}$. Different estuaries of the Sundarbans showed different trends, with Saptamukhi and Thakuran showing maximum and minimum DIC at the upper and 
Table 2. Physicochemical parameters, inorganic and organic C-related parameters and $\mathrm{CO}_{2}$ exchange flux across the water-atmosphere interface at the estuaries of the Sundarbans. Here, $W_{\mathrm{T}}$ is water temperature, DO is dissolved oxygen.

\begin{tabular}{lrrrrrrrrrrr}
\hline Station & $\begin{array}{r}W_{\mathrm{T}} \\
\left({ }^{\circ} \mathrm{C}\right)\end{array}$ & Salinity & $\begin{array}{r}\mathrm{DO} \\
\left(\mathrm{mg} \mathrm{L}^{-1}\right)\end{array}$ & $\mathrm{pH}$ & $\begin{array}{r}\mathrm{DIC} \\
(\mu \mathrm{M})\end{array}$ & $\begin{array}{r}\delta^{13} \mathrm{C}_{\mathrm{DIC}} \\
(\% \circ)\end{array}$ & $\begin{array}{r}\mathrm{DOC} \\
(\mu \mathrm{M})\end{array}$ & $\begin{array}{r}\mathrm{POC} \\
(\mu \mathrm{M})\end{array}$ & $\begin{array}{r}\delta^{13} \mathrm{C}_{\mathrm{POC}} \\
(\% \circ)\end{array}$ & $\begin{array}{r}p \mathrm{CO}_{2} \\
(\mu \mathrm{atm})\end{array}$ & $\begin{array}{r}F \mathrm{CO}_{2} \\
\left(\mu \mathrm{mol} \mathrm{m}^{-2} \mathrm{~h}^{-1}\right)\end{array}$ \\
\hline S1 & 28.50 & 12.74 & 6.65 & 8.02 & 1780 & -5.59 & 278 & 154 & -22.85 & 536 & 26.5 \\
$\mathrm{~S} 2$ & 28.00 & 16.02 & 6.65 & 8.02 & 1703 & -4.33 & 267 & 124 & -23.54 & 561 & 30.3 \\
$\mathrm{~S} 3$ & 28.00 & 16.69 & 6.61 & 8.12 & 1700 & -4.29 & 197 & 114 & -23.43 & 395 & 0.9 \\
S4 & 29.00 & 15.25 & 6.46 & 8.01 & 1861 & -5.27 & 315 & 93 & -23.68 & 543 & 27.6 \\
T1 & 29.00 & 14.30 & 6.56 & 8.05 & 1757 & -5.57 & 259 & 80 & -23.62 & 490 & 18.1 \\
T2 & 29.00 & 15.51 & 6.74 & 8.07 & 1727 & -4.79 & 182 & 106 & -23.21 & 456 & 11.9 \\
T3 & 28.50 & 16.55 & 6.46 & 8.11 & 1683 & -4.39 & 154 & 154 & -22.97 & 403 & 2.4 \\
M1 & 28.00 & 15.14 & 6.99 & 8.07 & 1711 & -5.93 & 282 & 264 & -23.07 & 443 & 9.4 \\
M2 & 28.00 & 15.14 & 6.91 & 8.12 & 1735 & -4.63 & 219 & 436 & -23.15 & 376 & -2.6 \\
M3 & 28.00 & 15.23 & 7.46 & 8.13 & 1736 & -5.30 & 222 & 287 & -23.62 & 401 & 1.9 \\
M4 & 28.50 & 14.78 & 6.84 & 8.04 & 1920 & -5.38 & 215 & 96 & -23.82 & 503 & 20.3 \\
\hline
\end{tabular}

Table 3. Physicochemical parameters, inorganic and organic C-related parameters and $\mathrm{CO}_{2}$ exchange flux across the water-atmosphere interface at the Hooghly estuary. Here, $W_{\mathrm{T}}$ is water temperature, DO is dissolved oxygen.

\begin{tabular}{lrrrrrrrrrrr}
\hline Station & $\begin{array}{r}W_{\mathrm{T}} \\
\left({ }^{\circ} \mathrm{C}\right)\end{array}$ & Salinity & $\begin{array}{r}\mathrm{DO} \\
\left(\mathrm{mg} \mathrm{L}^{-1}\right)\end{array}$ & $\mathrm{pH}$ & $\begin{array}{r}\mathrm{DIC} \\
(\mu \mathrm{M})\end{array}$ & $\begin{array}{r}\delta^{13} \mathrm{C}_{\mathrm{DIC}}(\%) \\
(\mu \mathrm{DOC})\end{array}$ & $\begin{array}{r}\mathrm{POC} \\
(\mu \mathrm{M})\end{array}$ & $\begin{array}{r}\delta^{13} \mathrm{C}_{\mathrm{POC}}(\%) \\
(\mu \mathrm{m})\end{array}$ & $\begin{array}{r}p \mathrm{CO}_{2} \\
(\mu \mathrm{atm})\end{array}$ & $\begin{array}{r}F \mathrm{CO}_{2} \\
\left(\mu \mathrm{mol} \mathrm{m}^{-2} \mathrm{~h}^{-1}\right)\end{array}$ \\
\hline $\mathrm{H} 1$ & 32.0 & 0.04 & 6.29 & 7.92 & 2700 & -6.98 & 244 & 313 & -25.34 & 2036 & 285.2 \\
$\mathrm{H} 2$ & 33.0 & 0.07 & 6.11 & 7.71 & 1678 & -8.38 & 304 & 177 & -25.19 & 2316 & 343.8 \\
$\mathrm{H} 3$ & 31.0 & 0.08 & 6.45 & 7.83 & 2498 & -6.70 & 235 & 286 & -25.95 & 2490 & 355.4 \\
$\mathrm{H} 4$ & 31.0 & 0.13 & 5.24 & 7.73 & 2446 & -7.38 & 243 & 254 & -25.40 & 2691 & 389.2 \\
$\mathrm{H} 5$ & 31.0 & 0.19 & 5.38 & 7.77 & 2355 & -7.56 & 340 & 130 & -25.67 & 2123 & 293.1 \\
$\mathrm{H} 6$ & 30.5 & 0.32 & 5.66 & 7.31 & 2157 & -8.61 & 308 & 116 & -24.07 & 4678 & 717.5 \\
$\mathrm{H} 7$ & 31.5 & 5.83 & 6.71 & 7.68 & 1829 & -6.79 & 662 & 145 & -24.70 & 1184 & 132.0 \\
$\mathrm{H} 8$ & 31.0 & 5.19 & 7.14 & 7.31 & 2023 & -6.78 & 354 & 139 & -23.47 & 3153 & 455.8 \\
$\mathrm{H} 9$ & 31.5 & 9.08 & 6.62 & 7.90 & 1915 & -6.08 & 332 & 161 & -23.53 & 665 & 44.9 \\
$\mathrm{H} 10$ & 31.5 & 9.72 & 6.17 & 8.08 & 1787 & -5.78 & 249 & 95 & -24.06 & 452 & 10.1 \\
$\mathrm{H} 11$ & 31.0 & 8.43 & 6.37 & 8.07 & 1977 & -7.21 & 358 & 95 & -25.94 & 486 & 15.6 \\
$\mathrm{H} 12$ & 31.5 & 5.83 & 7.40 & 8.29 & 1871 & -6.60 & 260 & 133 & -26.28 & 274 & -19.3 \\
$\mathrm{H} 13$ & 31.0 & 10.37 & 7.00 & 8.24 & 1843 & -5.57 & 394 & 129 & -24.72 & 267 & -19.8 \\
\hline
\end{tabular}

lower estuarine regions, with a reverse trend for $\delta^{13} \mathrm{C}_{\text {DIC }}$. However, for the Matla, no distinct spatial trend was noticed for both DIC and $\delta^{13} \mathrm{C}_{\mathrm{DIC}}$. In comparison to the estuarine surface waters, markedly higher DIC and lower $\delta^{13} \mathrm{C}_{\text {DIC }}$ were observed for the groundwater (Hooghly: DIC $=5655$ to $11756 \mu \mathrm{M}, \delta^{13} \mathrm{C}_{\mathrm{DIC}}=-12.66 \%$ to $-6.67 \%$; Sundarbans: $\mathrm{DIC}=7524$ to $13599 \mu \mathrm{M}, \delta^{13} \mathrm{C}_{\mathrm{DIC}}=-10.56 \%$ o to $-6.69 \%$; Table 4) and porewater samples (Sundarbans: $\mathrm{DIC}=13425 \mu \mathrm{M} ; \delta^{13} \mathrm{C}_{\text {DIC }}=-18.05 \%$; Table 4) collected from the Hooghly-Sundarbans system. The DOC in the Sundarbans varied from 154 to $315 \mu \mathrm{M}$ (mean: $235 \pm 49 \mu \mathrm{M}$; Table 2) with no distinct spatial variability. In comparison, $\sim 40 \%$ higher DOC was noticed in the Hooghly (235 to $662 \mu \mathrm{M}$; Table 3), reaching a peak in the mixing regime.

\subsection{Variability in particulate matter and $\delta^{13} C_{P O C}$}

In the Sundarbans, both SPM and POC varied over a wide range (SPM $=80$ to $741 \mathrm{mg} \mathrm{L}^{-1}$, mean: $241 \pm 197 \mathrm{mg} \mathrm{L}^{-1}$; $\mathrm{POC}=80$ to $436 \mu \mathrm{M}$, mean: $173 \pm 111 \mu \mathrm{M}$; Table 2) with no distinct spatial variability. Compared to that, SPM and POC in the Hooghly were relatively lower and varied from 38 to $289 \mathrm{mg} \mathrm{L}^{-1}$ and 95 to $313 \mu \mathrm{M}$ (Table 3), respectively, reaching maximum at the freshwater regime. The $\delta^{13} \mathrm{C}_{\mathrm{POC}}$ of the Sundarbans varied from $-23.82 \%$ to $-22.85 \%$ (mean: $-23.36 \pm 0.32 \%$ ), whereas in the Hooghly it varied from $-26.28 \%$ o to $-23.47 \%$ (mean: $-24.87 \pm 0.89 \%$ ).

\subsection{Variability in $\mathrm{pCO}_{2}$ and $\mathrm{FCO}_{2}$}

In the Sundarbans, surface water $p \mathrm{CO}_{2}$ varied from 376 to $561 \mu \mathrm{atm}$ (mean: $464 \pm 66 \mu \mathrm{atm}$; Table 2) with no spatial pattern. Compared to the Sundarbans, $\sim 3.8$ times higher $p \mathrm{CO}_{2}$ 
Table 4. The DIC concentrations and $\delta^{13} \mathrm{C}_{\mathrm{DIC}}$ of groundwater (GW) and porewater (PW) samples collected around the HooghlySundarbans system.

\begin{tabular}{llrr}
\hline Ecosystems & Station & DIC $(\mu \mathrm{M})$ & $\delta^{13} \mathrm{C}_{\text {DIC }}(\%$ ) \\
\hline Hooghly & H3GW & 11756 & -12.66 \\
& H4GW & 6230 & -7.85 \\
& H5GW & 6327 & -8.96 \\
& H6GW & 7026 & -11.27 \\
& H7GW & 5655 & -6.91 \\
& H11GW & 9115 & -7.67 \\
& H12GW & 6858 & -7.49 \\
& H13GW & 7258 & -7.21 \\
& Gangasagar GW & 7246 & -6.67 \\
\hline \multirow{2}{*}{ Sundarbans } & Lothian GW & 7524 & -6.84 \\
& Lothian PW & 13425 & -18.05 \\
& Kalash GW & 13599 & -6.69 \\
& Virat Bazar GW & 8300 & -10.56 \\
\hline
\end{tabular}

was estimated in the Hooghly estuary (267 to $4678 \mu \mathrm{atm}$; Table 3), reaching its peak in the freshwater regime. Except for one location at the Sundarbans (M2: $-42 \mu \mathrm{M})$ and two locations in the mixing regime at the Hooghly (H12: $-3.26 \mu \mathrm{M}$; H13: $-3.43 \mu \mathrm{M}), \mathrm{ECO}_{2}$ values were always positive in the Hooghly-Sundarbans system. The calculated $\mathrm{FCO}_{2}$ at the Hooghly estuary $\left(-19.8\right.$ to $717.5 \mu \mathrm{mol} \mathrm{m}{ }^{-2} \mathrm{~h}^{-1}$; mean: $231 \mu \mathrm{mol} \mathrm{m}{ }^{-2} \mathrm{~h}^{-1}$; Table 3) was $\sim 17$ times higher than the mangrove dominated estuaries of the Indian Sundarbans $\left(\mathrm{FCO}_{2}\right.$ : -2.6 to $30.3 \mu \mathrm{mol} \mathrm{m}{ }^{-2} \mathrm{~h}^{-1}$; Table 2$)$. Spatially, in the Hooghly, higher $\mathrm{FCO}_{2}$ was noticed in the freshwater regime ( 285.2 to $717.5 \mu \mathrm{mol} \mathrm{m}{ }^{-2} \mathrm{~h}^{-1}$ ) compared to the mixing regime, while no such distinct spatial trend was observed at the Sundarbans.

\section{Discussion}

Based on the results obtained during the present study, below we discuss different aspects of the $\mathrm{C}$ cycle within the Hooghly-Sundarbans system.

\subsection{Major drivers of DIC dynamics}

DIC concentrations observed in this study for the Hooghly were higher than that reported by Samanta et al. (2015) for the same season (DIC: 1700 to $2250 \mu \mathrm{M}$ ), whereas observed $\delta^{13} \mathrm{C}_{\mathrm{DIC}}$ were within their reported range $\left(\delta^{13} \mathrm{C}_{\mathrm{DIC}}\right.$ : $-11.4 \%$ to $-4.0 \%$ ). Statistically significant correlations between DIC-salinity $\left(r^{2}=0.43, p=0.015\right)$ and $\delta^{13} \mathrm{C}_{\mathrm{DIC}^{-}}-$ salinity $\left(r^{2}=0.58, p=0.003\right)$ in the Hooghly suggested the potential influence of marine and freshwater mixing on DIC and $\delta^{13} \mathrm{C}_{\mathrm{DIC}}$ in the estuary (Fig. 3a, b), rationalizing the application of a two-endmember mixing models. A twoendmember mixing model to decipher processes influencing
DIC chemistry has been applied earlier in the Hooghly estuary (Samanta et al., 2015).

Based on the methodology discussed earlier, calculated $\Delta \mathrm{C}$ for DIC ( $\Delta \mathrm{DIC} \sim-0.27$ to 0.17$)$ predicted a dominance of DIC addition $(n=4)$ over removal $(n=2)$ in the freshwater regime of the Hooghly, whereas only removal was evident in the mixing regime. In the case of $\Delta \delta^{13} \mathrm{C}$ for DIC $\left(\Delta \delta^{13} \mathrm{C}_{\mathrm{DIC}}\right)$, values were mostly positive $(n=9)$, i.e. measured $\delta^{13} \mathrm{C}_{\mathrm{DIC}}$ was higher compared to estimated $\delta^{13} \mathrm{C}_{\text {DIC }}$ due to conservative mixing. A deviation plot ( $\triangle \mathrm{DIC}$ vs. $\Delta \delta^{13} \mathrm{C}_{\text {DIC }}$; Fig. $3 \mathrm{c}$ ) for samples of the Hooghly showed the following patterns: (a) a decrease in $\triangle \mathrm{DIC}$ with increasing $\Delta \delta^{13} \mathrm{C}_{\mathrm{DIC}}(n=5)$, indicating phytoplankton productivity and/or outgassing of $\mathrm{CO}_{2}$ across the water-atmosphere interface, (b) a decrease in $\Delta \mathrm{DIC}$ with decreasing $\Delta \delta^{13} \mathrm{C}_{\mathrm{DIC}}$ $(n=4)$, indicating carbonate precipitation and (c) increase of $\Delta \mathrm{DIC}$ with increasing $\Delta \delta^{13} \mathrm{C}_{\mathrm{DIC}}(n=4)$ representing carbonate dissolution within the system.

Based on these calculations, both organic and inorganic processes (productivity, carbonate precipitation and dissolution) along with physical processes $\left(\mathrm{CO}_{2}\right.$ outgassing across the water-atmosphere interface) appeared to regulate DIC chemistry in the Hooghly estuary. Spatially, phytoplankton productivity and/or outgassing of $\mathrm{CO}_{2}$ appeared to regulate DIC in the mixing regime ( $n=5$ out of 7$)$ of the Hooghly. Earlier studies have advocated for high phytoplankton productivity in non-limiting nutrient conditions during the post-monsoon season in the Hooghly (Mukhopadhyay et al., 2002., 2006). However, based on the present data, particularly due to a lack of direct primary productivity measurements, it was difficult to spatially decouple individual contributions of primary productivity and $\mathrm{CO}_{2}$ outgassing in the mixing regime. In contrast to the mixing regime, carbonate precipitation and dissolution appeared to be dominant processes affecting DIC chemistry in the freshwater regime of the Hooghly.

In mangrove-dominated estuaries of the Sundarbans, observed $\delta^{13} \mathrm{C}_{\mathrm{DIC}}$ during this study were within the range $\left({ }^{13} \mathrm{C}_{\mathrm{DIC}}\right.$ : $-4.7 \pm 0.7 \%$ o) reported by Ray et al. (2018), whereas observed DIC concentrations were lower than their estimates (DIC: $2130 \pm 100 \mu \mathrm{mol} \mathrm{kg}^{-1}$ ). Our data also showed similarity with Khura and Trang rivers, two mangrove-dominated rivers of peninsular Thailand flowing towards the Andaman Sea, although from hydrological prospective these two systems are contrasting in nature (Sundarbans: narrow salinity gradient (12.74 to 16.69$)$ vs. Khura and Trang rivers: sharp salinity gradient $(\sim 0$ to 35$)$; Miyajima et al., 2009). Like Hooghly, the $\delta^{13} \mathrm{C}_{\mathrm{DIC}}-$ salinity relationship was statistically significant $\left(r^{2}=0.55, p=0.009\right)$ for the Sundarbans, but the DIC-salinity relationship remained insignificant ( $p=0.18)$ (Fig. 3d, e).

Given the dominance of mangroves in the Sundarbans, the role of mangrove-derived organic carbon (OC) mineralization may be important in regulating DIC chemistry in this ecosystem. Theoretically, $\Delta \mathrm{C}_{\text {Mangrove }}$ for DIC 

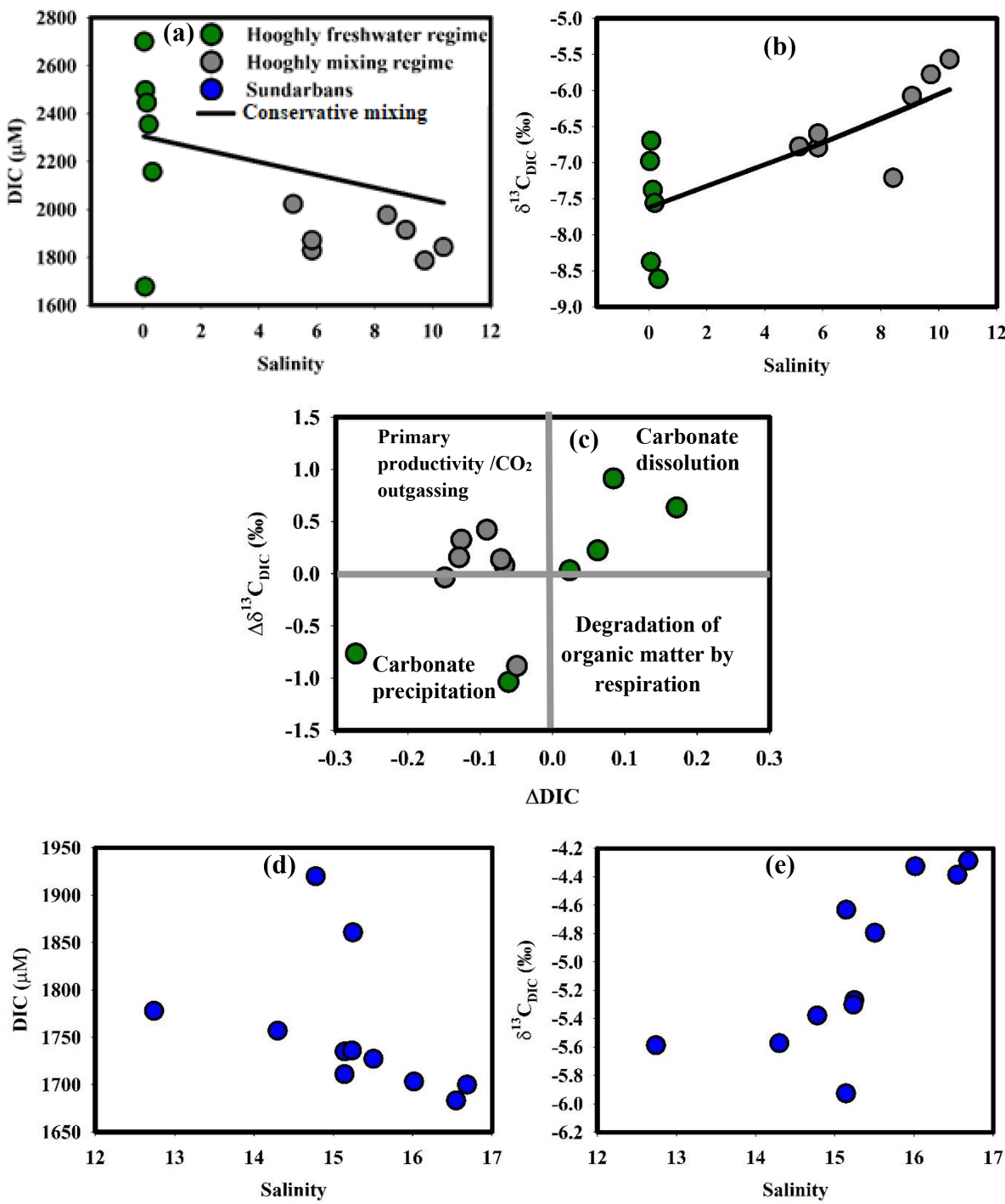

Figure 3. (a) DIC-salinity in the Hooghly, (b) $\delta^{13} \mathrm{C}_{\mathrm{DIC}}-$ salinity in the Hooghly, (c) $\Delta \mathrm{DIC}-\Delta \delta^{13} \mathrm{C}_{\mathrm{DIC}}$ in the Hooghly, (d) DIC-salinity in the Sundarbans and (e) $\delta^{13} \mathrm{C}_{\mathrm{DIC}}-$ salinity in the Sundarbans.

$\left(\Delta \mathrm{DIC}_{\text {Mangrove }}\right)$ estimated based on DIC $\left(\Delta \mathrm{DIC}_{\mathrm{M} 1}\right)$ and $\delta^{13} \mathrm{C}_{\mathrm{DIC}}\left(\triangle \mathrm{DIC} \mathrm{C}_{\mathrm{M} 2}\right)$ should be equal. The negative and unequal values of $\Delta \mathrm{DIC}_{\mathrm{M} 2}(-41$ to $62 \mu \mathrm{M})$ and $\Delta \mathrm{DIC} \mathrm{C}_{\mathrm{M} 1}$ $(-186$ to $11 \mu \mathrm{M})$ indicate a large DIC outflux over influx through mineralization of mangrove-derived OC in this tropical mangrove system. The removal mechanisms of DIC include $\mathrm{CO}_{2}$ outgassing across estuarine water-atmosphere boundary, phytoplankton uptake and export to the adjacent continental shelf region (northern BOB, Ray et al., 2018). The evidence for $\mathrm{CO}_{2}$ outgassing was found at almost all locations covered during the present study (10 out of 11 locations covered; see Sect. 4.4). Also, a recent study by Ray et al. (2018) estimated DIC export $\left(\sim 3.69 \mathrm{Tg} \mathrm{C} \mathrm{yr}^{-1}\right)$ from the estuaries of the Sundarbans as the dominant form of $\mathrm{C}$ export. Although data for primary productivity is not available for the study period, earlier studies have reported post- monsoon as the peak season for phytoplankton productivity (Biswas et al., 2007; Dutta et al., 2015). Given the evidence for the presence of DIC removal processes in the Sundarbans, a comprehensive study that measures rates of these processes with higher spatial and temporal coverages is desirable to understand the balance between influx and outflux of DIC in the Sundarbans.

Other than biogeochemical processes, factors such as groundwater and porewater exchange to the estuary might also play a significant role in estuarine DIC chemistry (Tait et al., 2016). High $p \mathrm{CO}_{2}$ and DIC, along with low $\mathrm{pH}$ and TAlk/DIC are general characteristics of groundwater, especially within carbonate aquifer region (Cai et al., 2003). Although all the parameters of groundwater inorganic $\mathrm{C}$ system (like $\mathrm{pH}$, TAlk and $p \mathrm{CO}_{2}$ ) were not measured during the present study, groundwater DIC was $\sim 5.57$ and 
$\sim 3.61$ times higher compared to mean surface water DIC in the Sundarbans and Hooghly. The markedly higher DIC in groundwater, as well as the similarity in its isotopic composition with estuarine DIC, may stand as a signal for the influence of groundwater on estuarine DIC, with a possibly greater influence in the Sundarbans than Hooghly as evident from the slope of the TAlk-DIC relationships (Hooghly: 0.98, Sundarbans: 0.03). In the Sundarbans, to the best of our knowledge, no report exists regarding groundwater discharge. Contradictory reports exist for the Hooghly, where Samanta et al. (2015) indicated groundwater contribution at a low-salinity regime (salinity $<10$, same as our salinity range) based on Ca measurement, which was not observed based on the $\mathrm{Ra}$ isotope measurement in an earlier study (Somayajulu et al., 2002). Porewater DIC in the Sundarbans was $\sim 7.63$ times higher than the estuarine water, indicating the possibility of DIC input from the adjoining mangrove system to the estuary through porewater exchange depending upon changes in hypsometric gradient during tidal fluctuation (i.e. tidal pumping). By using porewater-specific discharge and porosity at $0.008 \mathrm{~cm} \mathrm{~min}^{-1}$ and 0.58 (Dutta et al., 2013, 2015), respectively, during the post-monsoon season and extrapolating the flux value on a daily basis (i.e. for $12 \mathrm{~h}$ as tides are semidiurnal in nature), mean $F_{\text {DIC }}$ during the postmonsoon season was calculated as $\sim 770.4 \mathrm{mmol} \mathrm{m}^{-2} \mathrm{~d}^{-1}$. However, the significant impact of porewater on DIC may be limited only in mangrove creek water (samples not collected) as evident from the narrow variability of estuarine TAlk and DIC as well as no significant correlation between them $(p=0.93)$. A comprehensive investigation that measures rates of ground- and porewater-mediated DIC additions is needed to thoroughly understand their importance in controlling the DIC chemistry of the Hooghly-Sundarbans system.

From the above discussion, it appears that higher DIC in the Hooghly compared to the Sundarbans may be due to cumulative interactions between freshwater content to the individual estuaries as well as the degree of biogeochemical and hydrological processes. A relatively higher freshwater contribution in the Hooghly compared to the Sundarbans (as evident from salinity), as well as significant negative relationship between DIC and salinity, proved the significant impact of freshwater on DIC pool in the Hooghly. However, quantifications of other biogeochemical and hydrological processes are needed to decipher dominant processes affecting DIC dynamics in the Hooghly-Sundarbans system.

\subsection{DOC in the Hooghly-Sundarbans}

In the Hooghly, DOC concentrations observed during this study was higher than the range ( $226.9 \pm 26.2$ to $324 \pm 27 \mu \mathrm{M})$ reported by Ray et al. (2018), whereas observed DOC in the Sundarbans was comparable with their estimates $(262.5 \pm$ $48.2 \mu \mathrm{M})$. The marine water and freshwater mixing did not appear to exert major control over DOC in the Hooghly-
Sundarbans system as evident from the lack of significant correlations between DOC and salinity (Hooghly freshwater regime: $r^{2}=0.33, p=0.23$; Hooghly mixing regime: $r^{2}=$ $0.10, p=0.50$; Sundarbans: $r^{2}=0.27, p=0.10$, Fig. $4 a$ ). Our observation showed similarity with other Indian estuaries (Bouillon et al., 2003), with opposite reports from elsewhere (Raymond and Bauer, 2001; Abril et al., 2002). This indicates that DOC in this subtropical estuarine system is principally controlled by processes other than the mixing of two water masses.

Although it is difficult to accurately decipher processes influencing DOC without $\delta^{13} \mathrm{C}_{\mathrm{DOC}}$ data, some insights may be obtained from estimated $\triangle \mathrm{C}$ of DOC $(\triangle \mathrm{DOC})$. The estimated $\triangle \mathrm{DOC}$ in the Hooghly indicated both net addition $(n=3)$ and removal $(n=3)$ of DOC in the freshwater regime ( $\triangle \mathrm{DOC}=-0.16$ to 0.11$)$, whereas only net addition was evident throughout the mixing regime ( $\triangle \mathrm{DOC}=0.08$ to 1.74 ). In the Sundarbans, except the lower Thakuran (St. T3, $\Delta$ $\left.\mathrm{DOC}_{\mathrm{M} 1}=-20 \mu \mathrm{M}\right)$, net addition of mangrove-derived DOC was estimated throughout $\left(\triangle \mathrm{DOC}_{\mathrm{M} 1}=2\right.$ to $\left.134 \mu \mathrm{M}\right)$.

In an estuary, DOC can be added through in situ production (by benthic and pelagic primary producers), lysis of halophobic freshwater phytoplankton cells and POC dissolution. DOC can be removed through bacterial mineralization, flocculation as POC and photo-oxidation (Bouillon et al., 2006). At the Hooghly-Sundarbans system, no evidence for freshwater phytoplankton $\left({ }^{13} \mathrm{C}\right.$ : $-33 \%$ o to $-40 \%$; Freitas et al., 2001) was found from $\delta^{13} \mathrm{C}_{\mathrm{POC}}$, ruling out its potential effect on DOC. Although an indirect signal for phytoplankton productivity was observed in the freshwater regime from the $\delta^{13} \mathrm{C}_{\mathrm{DIC}}$ and POC relationship $\left(r^{2}=0.68\right.$, $p=0.05$ ), further evaluation of its impact on DOC was not possible due to the lack of direct measurement. Contradictory results exist regarding the influence of phytoplankton productivity on DOC. Some studies did not find a direct link between DOC and primary productivity (Boto and Wellington, 1988), whereas a significant contribution of phytoplankton production to building a DOC pool ( $\sim 8 \%$ to $40 \%)$ has been reported by others (Dittmar and Lara, 2001; Kristensen and Suraswadi, 2002).

In a nutrient-rich estuary like Hooghly, the lack of a significant relationship between DOC and $p \mathrm{CO}_{2}$ (freshwater regime: $p=0.69$, mixing regime: $p=0.67$, Fig. $4 \mathrm{~b}$ ) suggested either inefficient bacterial DOC mineralization or significant DOC mineralization compensated by phytoplankton $\mathrm{CO}_{2}$ uptake. However, a significant positive relationship between these two in the Sundarbans $\left(r^{2}=0.45, p=0.02\right.$, Fig. 4c) indicated an increase in aerobic bacterial activity with increasing DOC. In mangrove ecosystems, leaching of mangrove leaf litter as DOC is as fast as $~ 30 \%$ of mangrove leaf litter leaching as DOC is reported within the initial 9 days of degradation (Camilleri and Ribi, 1986). In the Sundarbans, mangrove leaf litter fall peaks during the post-monsoon season (Ray et al., 2011) and its subsequent significant leaching as DOC was evident during the 

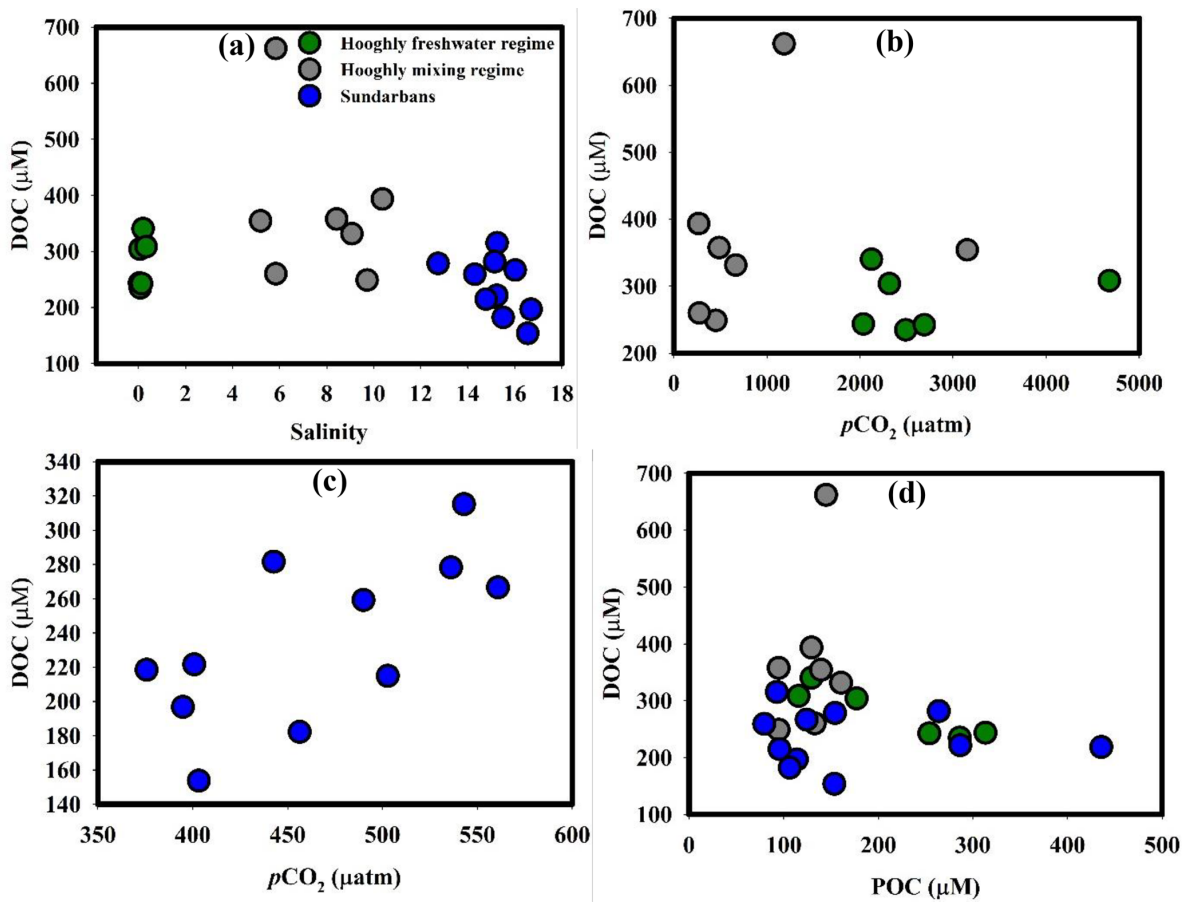

Figure 4. (a) DOC-salinity in the Hooghly-Sundarbans system, (b) DOC- $p \mathrm{CO}_{2}$ in the Hooghly, (c) $\mathrm{DOC}-p \mathrm{CO}_{2}$ in the Sundarbans and (d) DOC-POC in the Hooghly-Sundarbans system.

present study from relatively higher DOC compared to POC (DOC : $\mathrm{POC}=0.50$ to 3.39 , mean: $1.79 \pm 0.94 \%$ ). Our interpretation for Sundarbans corroborated with that reported by Ray et al. (2018) for the same system as well as with Bouillon et al. (2003) for the Godavari estuary, southern India.

Despite high-water residence time in the Hooghly ( 40 days during the post-monsoon season; Samanta et al., 2015) and in mangrove ecosystems like the Sundarbans (Alongi et al., 2005; Singh et al., 2016), DOC photooxidation may not be so potent due to unstable estuarine conditions in the Hooghly-Sundarbans system (Richardson number $<0.14$ ) having intensive vertical mixing with longitudinal dispersion coefficients of $784 \mathrm{~m}^{2} \mathrm{~s}^{-1}$ (Goutam et al., 2015; Sadhuram et al., 2005). The unstable condition may not favour DOC-POC interconversion as well but mediated by charged complexes and repulsion-attraction interactions, the interconversion partly depends upon variation in salinity. More specifically, the interconversion is efficient during initial mixing of freshwater (river) and seawater and the coagulation mostly completes within the salinity range $2-3$. This appeared to be the case in the Hooghly, where DOC and POC were negatively correlated in the freshwater regime $\left(r^{2}=0.86, p=0.007\right.$, Fig. $\left.4 \mathrm{~d}\right)$ but not in the mixing regime ( $p=0.43)$ or in the Sundarbans $(p=0.84)$.

Although estimated $\triangle \mathrm{DOC}$ indicated largely net DOC addition to the Hooghly-Sundarbans system, except leaf litter leaching in the Sundarbans, no significant evidence for other internal sources was found. This suggested a poten- tial contribution from external sources that may include industrial effluents and municipal waste-water discharge (i.e. surface runoff) in the freshwater regime of the Hooghly (Table 1). However, there are no direct DOC influx data available to corroborate the same. Relatively higher amounts of DOC compared to POC (DOC: $\mathrm{POC}>1$ ) at some locations $(\mathrm{H} 2, \mathrm{H} 5, \mathrm{H} 6)$ of the freshwater regime may stand as a signal for higher DOC contribution at those locations but it is not prudent to pinpoint its sources due to a lack of isotopic data. Considering significantly high DOC levels in waste water effluent (Katsoyiannis and Samara, 2006, 2007), along with fast degradation of biodegradable DOC ( $\sim 80 \%$ within $24 \mathrm{~h}$; Seidl et al., 1998) and residence time of Hooghly water (mentioned earlier), Samanta et al. (2015) suggested the possibility of anthropogenic DOC biodegradation during its transport in the estuary. Although anthropogenic inputs were mostly confined to the freshwater regime, relatively higher DOC in the mixing regime of the Hooghly compared to the freshwater regime suggested DOC input via some additional pathway, possibly groundwater discharge. The contribution of groundwater to the Hooghly estuary within the salinity range observed during the present study has been reported (Samanta et al., 2015). However, there is no report of groundwater-mediated DOC influx to the estuary. For mangrove-dominated ecosystems like the Sundarbans, a recent study by Maher et al. (2013) estimated $\sim 89 \%-92 \%$ of the total DOC export to be driven by groundwater advection. To understand spatial variability of DOC chemistry in the 
Hooghly-Sundarbans system, a thorough investigation that measures rates of groundwater and surface-runoff-mediated DOC addition is warranted.

Overall, on average, the concentration of DOC in the Hooghly was $\sim 40 \%$ higher than in the Sundarbans, which appeared to be due to the cumulative effect of contributions from freshwater and groundwater, higher anthropogenic inputs and DOC-POC interconversion. However, DOC inputs via other pathways may be dominant over freshwatermediated input as evident from the insignificant DOCsalinity relationship during the present study. To quantitatively understand the relative control of the above-mentioned contributors to the DOC pool in the Hooghly-Sundarbans system, the individual components need to be studied in detail.

\subsection{Major drivers of particulate organic matter}

The average POC during this study was relatively higher than the range (Hooghly: $40.3 \pm 1.1$ to $129.7 \pm 6.7 \mu \mathrm{M}$, Sundarbans: $45.4 \pm 7.5 \mu \mathrm{M}$ ) reported by Ray et al. (2018) for the Hooghly-Sundarbans system. However, it was within the range (51 to $750 \mu \mathrm{M}$; Sarma et al., 2014) reported for a large set of Indian estuaries. No significant SPM-salinity or POCsalinity relationships were observed during the present study (Fig. 5a, b), except for a moderate negative correlation between POC and salinity $\left(r^{2}=0.62, p=0.06\right)$ in the freshwater regime of the Hooghly. This inverse relationship may be linked to freshwater-mediated POC addition. Also, as described earlier, the contribution of POC via surface runoff is also a possibility in this regime due to the presence of several industries and large urban population (St. H2: Megacity Kolkata) that discharge industrial effluents and municipal waste water to the estuary on a regular basis (Table 1). A signal for surface-runoff-mediated POC addition was evident in the freshwater regime where $\sim 61 \%$ and $\sim 43 \%$ higher POC were observed at $\mathrm{H} 3$ and $\mathrm{H} 4$, respectively, compared to an upstream location (St. H2). However, based on the present data, it was not possible to decouple freshwater and surface-runoff-mediated POC inputs to the Hooghly estuary. A relatively lower contribution of POC to the SPM pool of the Sundarbans ( $0.66 \%$ to $1.23 \%$ ) compared to the Hooghly ( $0.96 \%$ to $4.22 \%$; Fig. $5 \mathrm{c}$ ) may be due to low primary production owing to a high SPM load (Ittekkot and Laane, 1991) as observed in the mangrove-dominated Godavari estuary in southern India (Bouillon et al., 2003).

In general, wide ranges for $\delta^{13} \mathrm{C}$ (rivers $\sim-28 \%$ to $-25 \%$; marine plankton $\sim-22 \%$ to $-18 \% ; \mathrm{C}_{3}$ plant $\sim$ $-32 \%$ o to $-24 \%$; $\mathrm{C}_{4}$ plants $\sim-13 \%$ o to $-10 \%$; freshwater algae and their detritus $\sim-30 \%$ to $-40 \%$ o) have been reported in the ecosystem (Smith and Epstein, 1971; Cerling et al., 1997; Bouillon et al., 2003; Bontes et al., 2006; Kohn, 2010; Marwick et al., 2015). In the Hooghly, our measured $\delta^{13} \mathrm{C}_{\mathrm{POC}}$ suggested an influx of POC via freshwater runoff as well as terrestrial $\mathrm{C}_{3}$ plants. Additionally, the es- tuary was also anthropogenically stressed during the postmonsoon season with measured $\delta^{13} \mathrm{C}_{\mathrm{POC}}$ within the range reported for sewage $\left(\delta^{13} \mathrm{C}_{\mathrm{POC}} \sim-28 \%\right.$ to $-14 \%$, Andrews et al., 1998; $\delta^{13} \mathrm{C}_{\mathrm{DOC}} \sim-26 \%$, Jin et al., 2018). In the mixing regime of the Hooghly, significantly lower $\delta^{13} \mathrm{C}_{\mathrm{POC}}$ at H11 and H12 compared to other sampling locations may be linked to localized ${ }^{13} \mathrm{C}$-depleted organic $\mathrm{C}$ influx to the estuary from adjacent mangroves and anthropogenic discharge, respectively.

In the estuaries of the Sundarbans, isotopic signatures of POC showed similarity with terrestrial $\mathrm{C}_{3}$ plants. Interestingly, despite being a mangrove-dominated estuary (salinity: 12.74 to 16.55$)$, no clear signature of either freshwater or mangrove-borne $\left(\delta^{13} \mathrm{C}\right.$ : mangrove leaf $\sim-28.4 \%$, soil $\sim-24.3 \%$, Ray et al., 2015, 2018) POC was evident from $\delta^{13} \mathrm{C}_{\mathrm{POC}}$ values, suggesting the possibility of significant POC modification within the system. Modification of POC within the estuaries of Indian subcontinent has been reported earlier (Sarma et al., 2014). Inter-estuary comparison revealed relatively lower average $\delta^{13} \mathrm{C}_{\mathrm{POC}}$ at the Hooghly (mean $\delta^{13} \mathrm{C}_{\mathrm{POC}}:-24.87 \pm 0.89 \%$ ) compared to the Sundarbans (mean $\delta^{13} \mathrm{C}_{\mathrm{POC}}$ : $-23.36 \pm 0.32 \%$ ), which appeared to be due to differences in degree of freshwater contribution, anthropogenic inputs (high in Hooghly vs. little/no in Sundarbans), the nature of terrestrial $C_{3}$ plant material (mangrove in the Sundarbans vs. others in Hooghly), as well as responsible processes for POC modification within the system.

To decipher processes involved in POC modification, estimated $\Delta \mathrm{C}$ for POC $(\triangle \mathrm{POC})$ in the Hooghly indicated both net addition $(n=3)$ and removal $(n=3)$ of POC in the freshwater regime ( $\triangle \mathrm{POC}=-0.45$ to 0.48$)$, whereas removal $(n=6)$ dominated over addition $(n=1)$ in the mixing regime ( $\triangle \mathrm{POC}=-0.39$ to 0.07 ). In an estuary, $\mathrm{POC}$ may be added through freshwater- and surface-runoff-mediated inputs, phytoplankton productivity and DOC flocculation. The removal of POC is likely due to settling at subtidal sediment, export to the adjacent continental shelf region, modification via conversion to DOC and degradation by respiration in the case of an oxygenated estuary.

The plot between $\Delta \delta^{13} \mathrm{C}$ for $\mathrm{POC}\left(\Delta \delta^{13} \mathrm{C}_{\mathrm{POC}}\right)$ and $\Delta \mathrm{POC}$ (Fig. 5d) indicated that different processes are active in different regimes of the Hooghly estuary. The decrease in $\triangle \mathrm{POC}$ with an increase in $\Delta \delta^{13} \mathrm{C}_{\mathrm{POC}}(n=4$ for the mixing regime and $n=1$ for the freshwater regime) suggested degradation of POC by respiration. This process did not appear to significantly impact the estuarine $\mathrm{CO}_{2}$ pool as evident from the POC $-p \mathrm{CO}_{2}$ relationship (freshwater regime: $p=0.29$, mixing regime: $p=0.50$; Fig. $5 \mathrm{e})$. A decrease in both $\triangle \mathrm{POC}$ and $\Delta \delta^{13} \mathrm{C}_{\mathrm{POC}}(n=2$ for mixing regime and $n=2$ for freshwater regime) supported the settling of POC to subtidal sediment. Despite high-water residence time, this process may not be effective in the Hooghly due to unstable estuarine conditions (described earlier). An increase in $\triangle \mathrm{POC}$ with a decrease in $\Delta \delta^{13} \mathrm{C}_{\mathrm{POC}}(n=2$ for the freshwater regime) indicated POC inputs via surface and freshwater 

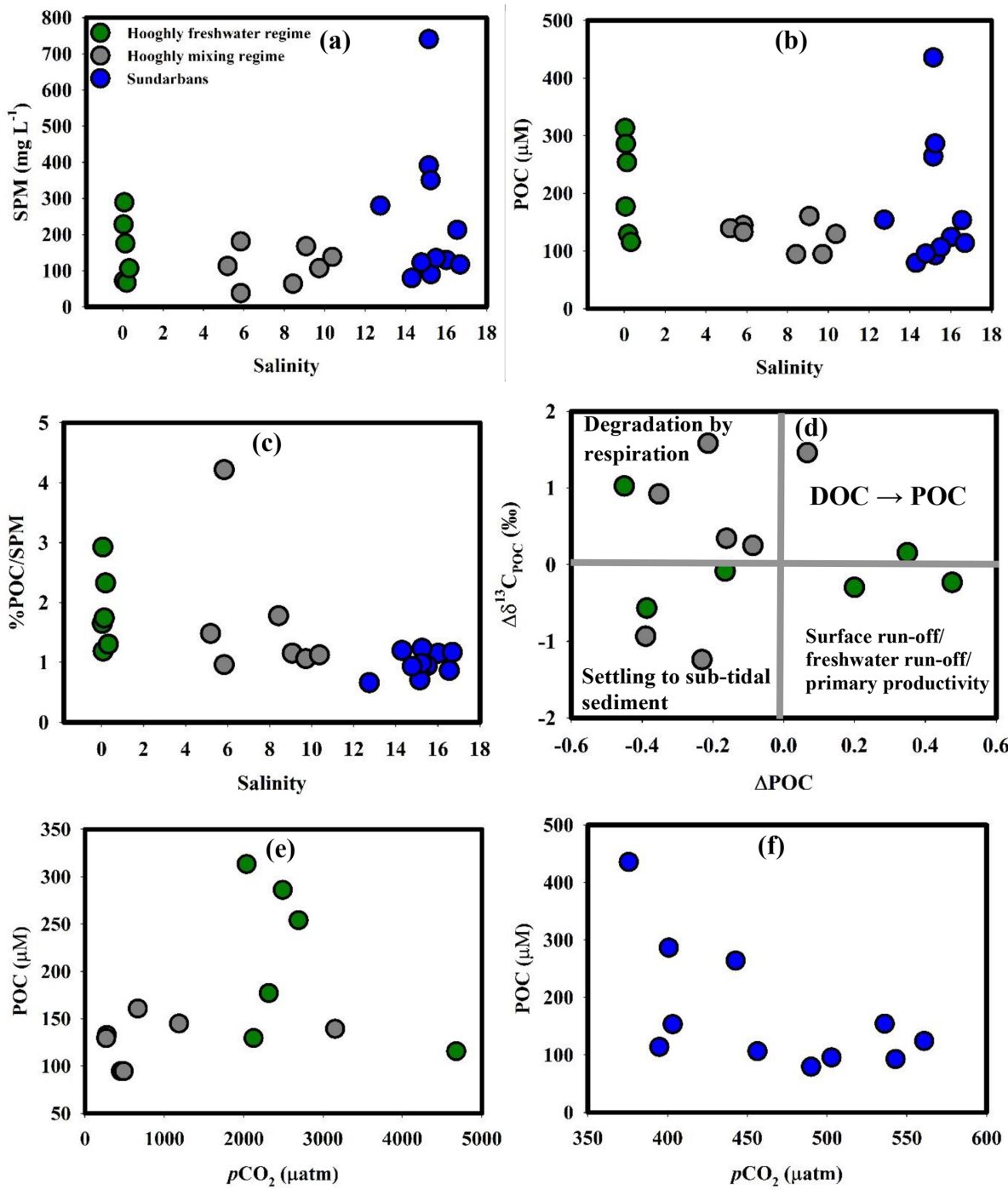

Figure 5. (a) SPM-salinity in the Hooghly-Sundarbans system, (b) POC-salinity in the Hooghly-Sundarbans system, (c) \% POC / SPMsalinity in the Hooghly-Sundarbans system, (d) $\Delta \mathrm{POC}-\Delta \delta{ }^{13} \mathrm{C}_{\mathrm{POC}}$ in the Hooghly, (e) $\mathrm{POC}-p \mathrm{CO}_{2}$ in the Hooghly and (f) $\mathrm{POC}-p \mathrm{CO} 2$ in the Sundarbans.

runoff as well as phytoplankton productivity. An increase in both $\triangle \mathrm{POC}$ and $\Delta \delta^{13} \mathrm{C}_{\mathrm{POC}}(n=1$ for the mixing regime and $n=1$ for the freshwater regime) may be linked to DOC-toPOC conversion by flocculation.

In the Sundarbans, negative and lower $\triangle \mathrm{POC}_{\mathrm{M} 2}(-209$ to $-28 \mu \mathrm{M})$ compared to $\triangle \mathrm{POC}_{\mathrm{M} 1}(-35$ to $327 \mu \mathrm{M})$ suggested DIC-like behaviour, i.e. simultaneous removal or modification along with the addition of mangrove-derived POC. No evidence for in situ POC-DOC exchange was found based on the POC-DOC relationship; however, the signal for degradation of POC by respiration was evident in the Sundarbans from the POC $-p \mathrm{CO}_{2}$ relationship $\left(r^{2}=0.37, p=0.05\right.$, Fig. 5f). Similarly to the Hooghly, despite high-water residence time in mangroves (Alongi et al., 2005; Singh et al., 2016), unstable estuarine conditions may not favour efficient settlement of POC at subtidal sediment. The export of POC from the Hooghly-Sundarbans system to the northern BOB, without significant in situ modification, is also a possibility. This export has been estimated to be $\sim 0.02$ to 0.07 and $\sim 0.58 \mathrm{Tg}$ annually for the Hooghly and Sundarbans, respectively (Ray et al., 2018).

\section{4 $\mathrm{pCO}_{2}$ and $\mathrm{FCO}_{2}$ in the Hooghly-Sundarbans}

The estimated $p \mathrm{CO}_{2}$ values for the Hooghly-Sundarbans system during this study were in the range (Cochin estuary: 150 to $3800 \mu \mathrm{atm}$, Gupta et al., 2009; Mandovi-Zuari estuary: 500 to $3500 \mu \mathrm{atm}$, Sarma et al., 2001) reported for other tidal estuaries of India. In the Sundarbans, barring three locations (S3, T3 and M2), a significant negative correlation between $p \mathrm{CO}_{2}$ and percent saturation of $\mathrm{DO}$ 

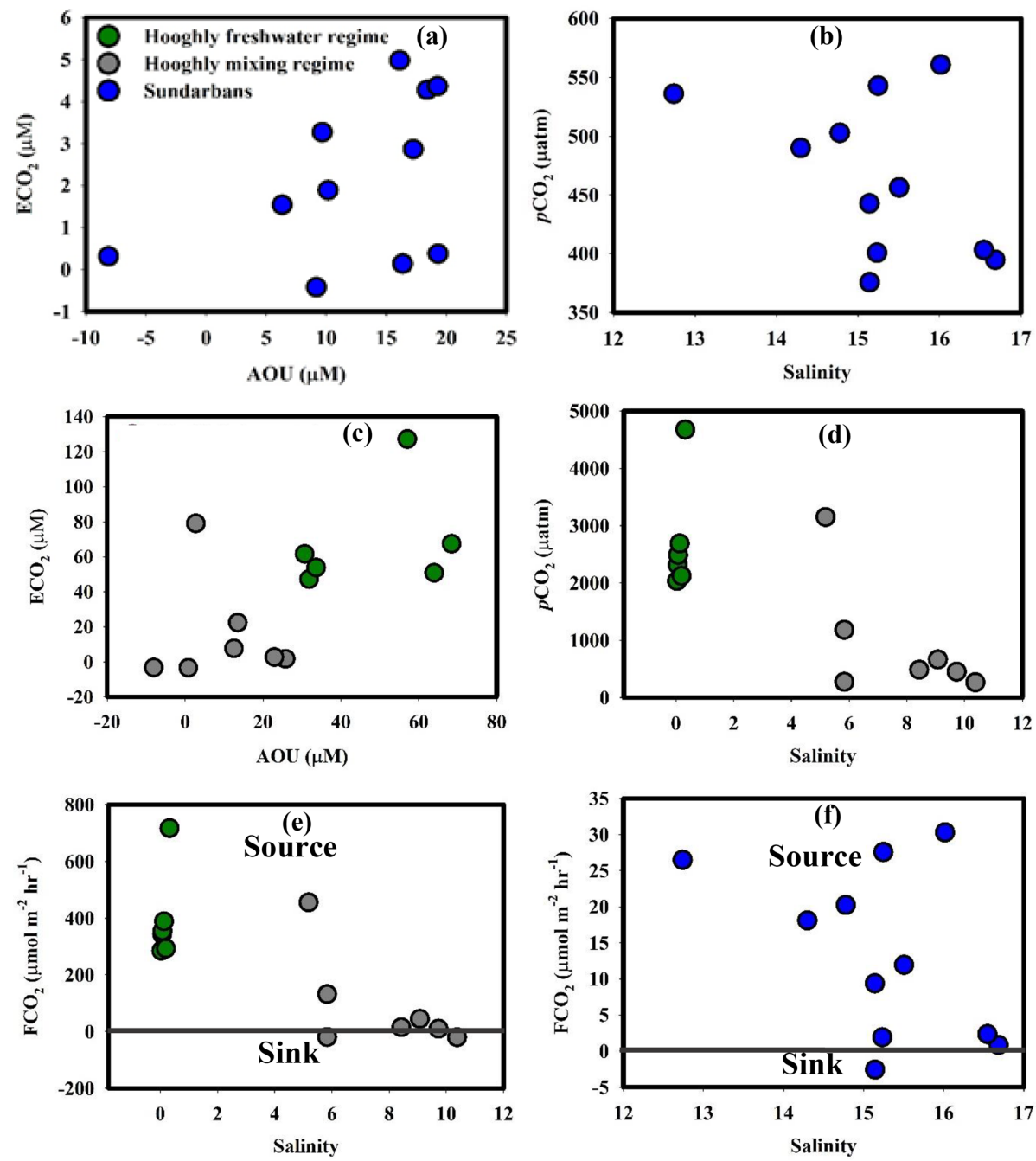

Figure 6. (a) $\mathrm{ECO}_{2}-\mathrm{AOU}$ in the Sundarbans, (b) $p \mathrm{CO}_{2}-$ salinity in the Sundarbans, (c) $\mathrm{ECO}_{2}-\mathrm{AOU}$ in the Hooghly, (d) $p \mathrm{CO}_{2}-\mathrm{salinity}$ in the Hooghly, (e) $\mathrm{FCO}_{2}$-salinity in the Hooghly and (f) $\mathrm{FCO}_{2}$-salinity in the Sundarbans.

$\left(r^{2}=0.76, p=0.005\right.$; figure not given) suggested the presence of processes, such as degradation of $\mathrm{OM}$ by respiration, responsible for controlling both $\mathrm{CO}_{2}$ production and $\mathrm{O}_{2}$ consumption in the surface estuarine water. Furthermore, significant positive correlation between $\mathrm{ECO}_{2}$ and $\mathrm{AOU}$ $\left(\mathrm{ECO}_{2}=0.057 \mathrm{AOU}+1.22, r^{2}=0.76, p=0.005, n=8\right.$; Fig. 6a) confirmed the effect of OM degradation by respiration on $\mathrm{CO}_{2}$ distribution, particularly in the upper region of the Sundarbans. Our observations were in agreement with a previous study in the Sundarbans (Akhand et al., 2016) as well as another subtropical estuary, Pearl River estuary, China (Zhai et al., 2005). However, a relatively lower slope for $\mathrm{ECO}_{2}-\mathrm{AOU}$ relationship (0.057) compared to the slope for Redfield respiration in a $\mathrm{HCO}_{3}^{-}$-rich environment $\left(\left(\mathrm{CH}_{2} \mathrm{O}\right)_{106}\left(\mathrm{NH}_{3}\right)_{16} \mathrm{H}_{3} \mathrm{PO}_{4}+138 \mathrm{O}_{2}+18 \mathrm{HCO}_{3}^{2-} \rightarrow\right.$ $124 \mathrm{CO}_{2}+140 \mathrm{H}_{2} \mathrm{O}+16 \mathrm{NO}_{3}^{-}+\mathrm{HPO}_{4}^{2-} ; \quad \Delta \mathrm{CO}_{2}$ : $\left(-\Delta \mathrm{O}_{2}\right)=124 / 138=0.90$, Zhai et al., 2005) suggested lower production of $\mathrm{CO}_{2}$ than expected from Redfield respiration. This may be linked to the formation of low molecular weight $\mathrm{OM}$ instead of the final product $\left(\mathrm{CO}_{2}\right)$ during aerobic $\mathrm{OM}$ respiration (Zhai et al., 2005). Moreover, the $p \mathrm{CO}_{2}$-salinity relationship $(p=0.18$, Fig. $6 \mathrm{~b})$ confirmed no significant effect of freshwater and marine water contribution on variability of $p \mathrm{CO}_{2}$ in the Sundarbans. Other potential sources of $\mathrm{CO}_{2}$ to the mangrove-dominated Sundarbans could be groundwater (or pore water) exchange across the intertidal mangrove sediment-water interface. Although based on our own data set, it is not possible to confirm the same. However, relatively higher $p \mathrm{CO}_{2}$ levels during low tide compared to high tide at the Matla estuary in the Sundarbans (Akhand et al., 2016) as well as in other estuarine mangrove systems worldwide (Bouillon et al., 2007; Call et al., 2015; Rosentreter et al., 2018) suggested groundwater (or pore water) exchange to be a potential $\mathrm{CO}_{2}$ source in such systems. 
Unlike the Sundarbans, the $\mathrm{ECO}_{2}-\mathrm{AOU}$ relationship did not confirm the significant impact of OM degradation by respiration on $\mathrm{CO}_{2}$ in either freshwater $(p=0.50)$ or mixing regimes $(p=0.75)$ of the Hooghly (Fig. 6c). Overall, $p \mathrm{CO}_{2}$ in the freshwater regime of the Hooghly was significantly higher compared to the mixing regime (Table 3 ), which may be linked to additional $\mathrm{CO}_{2}$ supply in the freshwater regime via freshwater or surface runoff from adjoining areas (Table 1). Inter-estuary comparison of $p \mathrm{CO}_{2}$ also revealed higher average $p \mathrm{CO}_{2}$ in the Hooghly by $\sim 1291 \mu$ atm compared to the Sundarbans, which was largely due to significantly higher $p \mathrm{CO}_{2}$ in the freshwater regime of the Hooghly (Tables 2 and 3). A lack of negative correlation between $p \mathrm{CO}_{2}$ and salinity in freshwater regime (Fig. 6d) of the Hooghly suggested a limited contribution of $\mathrm{CO}_{2}$ due to freshwater input. Therefore, $\mathrm{CO}_{2}$ supply via surface runoff may be the primary reason for higher $p \mathrm{CO}_{2}$ in the Hooghly estuary.

Positive mean $\mathrm{FCO}_{2}$ clearly suggested the HooghlySundarbans system to be a net source of $\mathrm{CO}_{2}$ to the regional atmosphere post-monsoon (Fig. 6e, f). Specifically, from regional climate and environmental change perspectives, the anthropogenically influenced Hooghly estuary was a relatively greater source of $\mathrm{CO}_{2}$ to the regional atmosphere compared to the mangrove-dominated Sundarbans $\left(\left[F \mathrm{CO}_{2}\right]_{\text {Hooghly }}:\left[F \mathrm{CO}_{2}\right]_{\text {Sundarbans }}=17\right)$. However, despite being a $\mathrm{CO}_{2}$ source, $F \mathrm{FO}_{2}$ measured for the estuaries of the Sundarbans were considerably lower compared to global mean $\mathrm{FCO}_{2}$ reported for the mangrove-dominated estuaries ( $\sim 43$ to $59 \mathrm{mmol} \mathrm{C} \mathrm{m}^{-2} \mathrm{~d}^{-1}$; Call et al., 2015). Similarly, $\mathrm{FCO}_{2}$ measured for the Hooghly estuary were relatively lower compared to some Chinese estuarine systems (Pearl River inner estuary: $46 \mathrm{mmol} \mathrm{m}^{-2} \mathrm{~d}^{-1}$, Guo et al., 2009; Yangtze River estuary: $41 \mathrm{mmol} \mathrm{m}^{-2} \mathrm{~d}^{-1}$, Zhai et al., 2007).

The difference in $F \mathrm{CO}_{2}$ between the Hooghly and Sundarbans may be due to variability in $p \mathrm{CO}_{2}$ level as well as micrometeorological and physicochemical parameters controlling gas transfer velocity across the water-atmosphere interface. Quantitatively, the difference in $k$ values for the Hoogly and Sundarbans were not large $\left(k_{\text {Sundarbans }}-k_{\text {Hooghly }} \sim\right.$ $0.031 \mathrm{~cm} \mathrm{~h}^{-1}$ ). Therefore, large difference in $\mathrm{FCO}_{2}$ between these two estuarine systems may be due to a difference in $p \mathrm{CO}_{2}$. Taken together, supporting our hypothesis, it appears that differences in land use and degrees of anthropogenic influence have the potential to alter the $\mathrm{C}$ biogeochemistry of aquatic ecosystems with anthropogenically stressed aquatic systems acting as a relatively greater source of $\mathrm{CO}_{2}$ to the regional atmosphere than mangrove-dominated ones.

\section{Conclusions}

The present study focused on investigating different aspects of $\mathrm{C}$ biogeochemistry of the anthropogenically affected
Hooghly estuary and mangrove dominated estuaries of the Sundarbans during the post-monsoon season. Considering the different natures and quantities of supplied organic matter within these two contrasting systems, it was hypothesized in this study that $\mathrm{C}$ metabolism in these two estuaries was different with higher $\mathrm{CO}_{2}$ exchange flux from the anthropogenically influenced estuary compared to the mangrovedominated one. The results obtained during the study supported this hypothesis with significant differences in physicochemical parameters and active biogeochemical processes in these two estuaries. While freshwater intrusion, along with inorganic and organic $\mathrm{C}$ metabolisms, appeared to shape DIC dynamics in the Hooghly, significant DIC removal (via $\mathrm{CO}_{2}$ outgassing, phytoplankton uptake as well as export to adjoining continental shelf regions) and the influence of groundwater were noticed in the Sundarbans. Relatively higher DOC concentration in the Hooghly compared to the Sundarbans was due to cumulative interactions among anthropogenic inputs, DOC-POC interconversion and groundwater contribution. Freshwater runoff, terrestrial $\mathrm{C}_{3}$ plants and anthropogenic inputs contributing to the POC pool in the Hooghly, whereas a contribution from $\mathrm{C}_{3}$ plants was dominant at the Sundarbans. Surface runoff from adjoining areas in the Hooghly and degradation of OM by respiration in the Sundarbans largely controlled $p \mathrm{CO}_{2}$ in the system. Overall, the entire Hooghly-Sundarbans system acted as a source of $\mathrm{CO}_{2}$ to the regional atmosphere with $\sim 17$ times higher emission from the Hooghly compared to the Sundarbans, suggesting a significant role played by an anthropogenically stressed estuarine system from regional climate change perspectives.

Data availability. Data used in the manuscript are presented in tables (Tables 2, 3 and 4) of the manuscript.

Author contributions. MKD and SK designed the study. MKD collected and analysed samples with RM and PS. MKD and SK interpreted the data and drafted the manuscript. SKM provided a facility with which to measure basic physicochemical parameters and DOC.

Competing interests. The authors declare that they have no conflict of interest.

Special issue statement. This article is part of the special issue "Human impacts on carbon fluxes in Asian river systems". It is not associated with a conference. 
Acknowledgements. MKD is thankful to Physical Research Laboratory (PRL) postdoctoral fellowship programme for providing fellowship. Authors are thankful to ISRO-GBP for financial support and Sundarbans Biosphere Reserve for their permission to carry out the sampling. Thanks to Rishmita Mukherjee and Avanti Acharya for their help during field observations. We also thank two anonymous reviewers and the associate editor for valuable comments, which significantly improved the quality of the manuscript.

Edited by: Ji-Hyung Park

Reviewed by: two anonymous referees

\section{References}

Abril, G., Nogueira, E., Hetcheber, H., Cabeçadas, G., Lemaire, E., and Brogueira, M. J.: Behaviour of organic carbon in nine contrasting European estuaries, Estuar. Coast. Shelf Sci., 54, 241262, https://doi.org/10.1006/ecss.2001.0844, 2002.

Akhand, A., Chandra, A., Dutta, S., and Hazra, S.: Air- water carbon dioxide exchange dynamics along the estuarine transition zone of Sunderban, northern Bay of Bengal, India, Indian J. Geo-Mar. Sci. 41, 111-116, 2012.

Akhand, A., Chanda, A., Manna, S., Das, S., Hazra, S., Roy, R., Choudhury, S. B., Rao, K. H., Dadhwal, V. K., Chakraborty, K., and Mostofa, K. M. G.: A comparison of $\mathrm{CO}_{2}$ dynamics and airwater fluxes in a river dominated estuary and a mangrove dominated marine estuary, Geophys. Res. Lett., 43, 11726-11735, https://doi.org/10.1002/2016GL070716, 2016.

Alling, V., Porcelli, D., Morth, C.-M., Anderson, L. G., SanchezGarcia, L., Gustafsson, O., Andersson, P. S., and Humborg, C.: Degradation of terrestrial organic carbon, primary production and out-gassing of $\mathrm{CO}_{2}$ in the Laptev and East Siberian Seas as inferred from $\delta^{13} \mathrm{C}$ values of DIC, Geochim. Cosmochim. Ac., 95, 143-159, https://doi.org/10.1016/j.gca.2012.07.028, 2012.

Alongi, D. M.: Carbon cycling and storage in mangrove forests, Ann. Rev. Mar. Sci., 6, 195-219, https://doi.org/10.1146/annurev-marine-010213-135020, 2014.

Alongi, D. M. and Mukhopadhyay, S. K.: Contribution of mangroves to coastal carbon cycling in low latitude seas, Agr. Forest Meteorol., 213, 266-272, https://doi.org/10.1016/j.agrformet.2014.10.005, 2014.

Alongi, D. M., Ramanathan, A. L., Kannan, L., Tirendi, F., Trott, L. A., and Prasad, M. B. K.: Human induced disturbance on benthic microbial metabolism in the Pichavaram mangroves, Vellar Coleroon estuarine complex, India, Mar. Biol., 147, 1033-1044, https://doi.org/10.1007/s00227-005-1634-5, 2005.

Andrews, J. E., Greenway, A. M., and Dennis, P. F.: Combined carbon isotope and $\mathrm{C} / \mathrm{N}$ ratios as indicators of source and fate of organic matter in a poorly flushed, tropical estuary, Hunts Bay, Kingston Harbour, Jamaica, Estuar. Coast. Shelf Sci., 46, 743456, https://doi.org/10.1006/ecss.1997.0305, 1998.

Barnes, J., Ramesh, R., Purvaja, R., Nirmal Rajkumar, A., Senthil Kumar, B., and Krithika, K.: Tidal dynamics and rainfall control $\mathrm{N}_{2} \mathrm{O}$ and $\mathrm{CH}_{4}$ emissions from a pristine mangrove creek, Geophys. Res. Lett., 33, L15405, https://doi.org/10.1029/2006GL026829, 2006.

Bauer, J. E., Cai, W. J., Raymond, P. A., Bianchi, T. S., Hopkinson, C. S., and Regnier, P. A. G.: The changing carbon cycle of the coastal ocean, Nature, 504, 61-70, https://doi.org/10.1038/nature12857, 2013.

Bhavya, P. S., Kumar, S., Gupta, G. V. M., and Sudheesh, V.: Carbon uptake rates in the Cochin estuary and adjoining coastal Arabian Sea, Estuar. Coast., 40, 447-456, https://doi.org/10.1007/s12237-016-0147-4, 2017.

Bhavya, P. S., Kumar, S., Gupta, G. V. M., Sudharma, K. V., and Sudheesh, V.: Spatial-temporal variation in $\delta^{13} \mathrm{C}_{\text {DIC }}$ of a tropical eutrophic estuary (Cochin estuary, India), Cont. Shelf Res., 153, 75-85, https://doi.org/10.1016/j.csr.2017.12.006, 2018.

Biswas, H., Mukhopadhyay, S. K., De, T. K., Sen, S., and Jana, T. K.: Biogenic controls on the air-water carbon dioxide exchange in the Sundarban mangrove environment, northeast coast of Bay of Bengal, India, Limnol. Oceanogr., 49, 95-101, https://doi.org/10.4319/lo.2004.49.1.0095, 2004.

Biswas, H., Mukhopadhyay, S. K., Sen, S., and Jana, T. K.: Spatial and temporal patterns of methane dynamics in the tropical mangrove dominated estuary, NE Coast of Bay of Bengal, Indian J. Mar. Syst., 68, 55-64, https://doi.org/10.1016/j.jmarsys.2006.11.001, 2007.

Bontes, B. M., Pel, R., Ibelings, B. W., Boschker, H. T. S., Middelburg, J. J., and Van Donk, E.: The effects of biomanipulation on the biogeochemistry, carbon isotopic composition and pelagic food web relations of a shallow lake, Biogeosciences, 3, 69-83, https://doi.org/10.5194/bg-3-69-2006, 2006.

Borges, A. V., Delille, B., Schiettecatte, L.-S., Gazeau, F., Abril, G., and Frankignoulle, M.: Gas transfer velocities of $\mathrm{CO}_{2}$ in three European estuaries (Randers Fjord, Scheldt and Thames), Limnol. Oceanogr., 49, 1630-1641, https://doi.org/10.4319/lo.2004.49.5.1630, 2004.

Borges, A. V., Delille, B., and Frankignoulle, M.: Budgeting sinks and sources of $\mathrm{CO}_{2}$ in the coastal ocean: Diversity of ecosystems counts, Geophys. Res. Lett., 32, L14601, https://doi.org/10.1029/2005gl023053, 2005.

Boto, K. G. and Wellington, J. T.: Seasonal variations in concentrations and fluxes of dissolved organic and inorganic materials in a tropical, tidally dominated waterway, Mar. Ecol. Prog. Ser., 50, 151-160, 1988.

Bouillon, S., Frankignoulle, M., Dehairs, F., Velimirov, B., Eiler, A., Etcheber, H., Abril, G., and Borges, A. V.: Inorganic and organic carbon biogeochemistry in the Gautami Godavari estuary (Andhra Pradesh, India) during pre-monsoon: the local impact of extensive mangrove forests, Global Biogeochem. Cy., 17, 1114, https://doi.org/10.1029/2002GB002026, 2003.

Bouillon, S., Korntheuer, M., Baeyens, W., and Dehairs, F.: A new automated setup for stable isotope analysis of dissolved organic carbon, Limnol. Oceanogr., 216-226, https://doi.org/10.4319/lom.2006.4.216, 2006.

Bouillon, S., Dehairs, F., Velimirov, B., Abril, G., and Borges, A. V.: Dynamics of organic and inorganic carbon across contiguous mangrove and seagrass systems (Gazi Bay, Kenya), J. Geophys. Res., 112, G02018, https://doi.org/10.1029/2006JG000325, 2007.

Bouillon, S., Borges, A. V., Castañeda-Moya, E., Diele, K., Dittmar, T., Duke, N. C., Kristensen, E., Lee, S. Y., Marchand, C., Middelburg, J. J., Rivera-Monroy, V. H., Smith, T. J., and Twilley, R. R.: Mangrove production and carbon sinks: A revision of global budget estimates, Global Biogeochem. Cy., 22, GB2013, https://doi.org/10.1029/2007GB003052, 2008. 
Cai, W.-J.: Estuarine and coastal ocean carbon paradox: $\mathrm{CO}_{2}$ sinks or sites of terrestrial carbon incineration?, Annu. Rev. Mar. Sci., 3, 123-145, 2011.

Cai, W.-J., Wang, Y., Krest, J., and Moore, W. S.: The geochemistry of dissolved inorganic carbon in a surficial groundwater aquifer in North Inlet, South Carolina and the carbon fluxes to the coastal ocean, Geochim. Cosmochim. Ac., 67, 631-637, https://doi.org/10.1016/S0016-7037(02)01167-5, 2003.

Cai, W.-J., Dai, M., and Wang, Y.: Air-sea exchange of carbon dioxide in ocean margins: A province-based synthesis, Geophys. Res. Lett., 33, 2-5, 2006.

Call, M., Maher, D. T., Santos, I. R., Ruiz-Halpern, S., Mangion, P., and Sanders, C. J., Erler, D. V., Oakes, J. M., Rosentreter, J., Murry, R., and Eyre, B. D: Spatial and temporal variability of carbon dioxide and methane fluxes over semidiurnal and spring-neap-spring timescales in a mangrove creek, Geochim. Cosmochim. Ac., 150, 211-225, https://doi.org/10.1016/j.gca.2014.11.023, 2015.

Camilleri, J. C. and Ribi, G.: Leaching of dissolved organic carbon (DOC) from dead leaves, formation of flakes from DOC, and feeding on flakes by crustaceans in mangroves, Mar. Biol., 91, 337-344, 1986.

Carpenter, I. H., Bradford, W. L., and Grant, V.: Processes affecting the composition of estuarine waters, in: Estuarine Research, 1, edited by: Cronin, L. E., Academic, 188-214, 1975.

Cerling, T. E., Harris, J. H., MacFadden, B. J., Leakey, M. G., Quadek, J., Eisenmann, V., and Ehleringer, J. R.: Global vegetation change through the Miocene/Pliocene boundary, Nature, 389, 153-158, https://doi.org/10.1038/38229, 1997.

Chen, C.-T. A. and Borges, A. V.: Reconciling opposing views on carbon cycling in the coastal ocean: Continental shelves as sinks and near-shore ecosystems as sources of atmospheric $\mathrm{CO}_{2}$, Deep-Sea. Res. Pt. II, 56, 578-590, 2009.

CIFRI: Present status of Hilsa in Hooghly - Bhagirathi river, Central Inland Fisheries Research Institute, available at: http:// cifri.ernet.in/Bulletins/Bulletin_No.179.pdf (last access: 10 May 2018), 2012.

Cotovicz Jr., L. C., Knoppers, B. A., Brandini, N., Costa Santos, S. J., and Abril, G.: A strong $\mathrm{CO}_{2}$ sink enhanced by eutrophication in a tropical coastal embayment (Guanabara Bay, Rio de Janeiro, Brazil), Biogeosciences, 12, 6125-6146, https://doi.org/10.5194/bg-12-6125-2015, 2015.

Dittmar, T. and Lara, R. J.: Driving forces behind nutrient and organic matter dynamics in a mangrove tidal creek in north Brazil, Estuar. Coast. Shelf Sci., 52, 249-259, https://doi.org/10.1006/ecss.2000.0743, 2001.

Dittmar, T., Hertkorn, N., Kattner, G., and Lara, R. J.: Mangroves, a major source of dissolved organic carbon to the oceans, Global Biogeochem. Cy., 20, GB1012, https://doi.org/10.1029/2005gb002570, 2006.

Donato, D. C., Kauffman, J. B., Kurnianto, S., Stidham, M., and Murdiyarso, D.: Mangroves among the most carbonrich forests in the tropics, Nat. Geosci., 4, 293-297, https://doi.org/10.1038/NGEO1123, 2011.

Dutta, K., Ravi Prasad, G. V., Ray, D. K., and Raghav, K.: Decadal changes of Radiocarbon in the surface Bay of Bengal: Three decades after GEOSECS and one decade after WOCE, Radiocarbon, 52, 1191-1196, 2010.
Dutta, M. K., Chowdhury, C., Jana, T. K., and Mukhopadhyay, S. K.: Dynamics and exchange fluxes of methane in the estuarine mangrove environment of Sundarbans, NE coast of India, Atmos. Environ., 77, 631-639, https://doi.org/10.1016/j.atmosenv.2013.05.050, 2013.

Dutta, M. K., Mukherkjee, R., Jana, T. K., and Mukhopadhyay, S. K.: Biogeochemical dynamics of exogenous methane in an estuary associated to a mangrove biosphere; the Sundarbans, NE coast of India, Mar. Chem., 170, 1-10, https://doi.org/10.1016/j.marchem.2014.12.006, 2015.

Dutta, M. K., Bianchi, T. S., and Mukhopadhyay, S. K.: Mangrove methane biogeochemistry in the Indian Sundarbans: a proposed budget, Front. Mar. Sci., 4, 187, https://doi.org/10.3389/fmars.2017.00187, 2017.

Frankignoulle, M. and Borges, A. V.: Direct and indirect $p \mathrm{CO}_{2}$ measurements in a wide range of $p \mathrm{CO}_{2}$ and salinity values (the Scheldt estuary), Aquat. Geochem., 7, 267-273, https://doi.org/10.1023/A:1015251010481, 2001.

Frankignoulle, M., Abril, G., Borges, A., Bourge, I., Canon, C., Delille, B., Libert, E., and Théate, J.-M.: Carbon dioxide emission from European estuaries, Science, 282, 434-436, https://doi.org/10.1126/science.282.5388.434, 1998.

Freitas, H. A., Pessenda, L. C. R., Aravena, R., Gouveia, S. E. M., Ribeiro, A. S., and Boulet, R.: Late quaternary vegetation dynamics in the southern Amazon Basin inferred from carbon isotopes in soil organic matter, Quaternary Res., 55, 39-46, https://doi.org/10.1006/qres.2000.2192 2001.

Fry, B.: Conservative mixing of stable isotopes across estuarine salinity gradients: a conceptual framework for monitoring watershed influences on downstream fisheries production, Estuaries, 25, 264-271, https://doi.org/10.1007/BF02691313, 2002.

Ganguly, D., Dey, M., Mandal, S. K., De, T. K., and Jana, T. K.: Energy dynamics and its implication to biosphere-atmosphere exchange of $\mathrm{CO}_{2}, \mathrm{H}_{2} \mathrm{O}$ and $\mathrm{CH}_{4}$ in a tropical mangrove forest canopy, Atmos. Environ., 42, 4172-4184, 2008.

Ganguly, D., Dey, M., Sen, S., and Jana, T. K.: Biosphere-atmosphere exchange of NOx in the tropical mangrove forest, J. Geophys. Res., 114, G04014, https://doi.org/10.1029/2008JG000852, 2009.

Gattuso, J.-P., Frankignoulle, M., Bourge, I., Romaine, S., and Buddemeier, R. W.: Effect of calcium carbonate saturation of seawater on coral calcification, Global Planet. Change, 18, 37-46, https://doi.org/10.1016/S0921-8181(98)00035-6, 1998.

Ghosh, B. B., Ray, P., and Gopalakrishnan, V.: Survey and characterization of waste water discharged into the Hooghly Estuary, J. Inland Fishery Soc. India, 4, 2-10, 1973.

Giri, C., Ochieng, E., Tieszen, L., Zhu, Z., Singh, A., Loveland, T., Masek, J., and Duke, N.: Status and distribution of mangrove forests of the world using earth observation satellite data, Glob. Ecol. Biogeogr., 20, 154-159, 2011.

Goutam, K. S., Tanaya, D., Anwesha, S., Sharanya, C., and Meenakshi, C.: Tide and mixing characteristics in Sundarbans Estuarine River system, Hydrol. Current Res., 6, 204, https://doi.org/10.4172/2157-7587.1000204, 2015.

Grasshoff, K., Ehrharft, M., and Kremling, K.: Methods of Seawater Analysis, 2nd Edn., Weinheim, Verlag Chemie, 1983.

Guo, X., Dai, M., Zhai, W., Cai, W.-J., and Chen, B.: $\mathrm{CO}_{2}$ flux and seasonal variability in a large subtropical estuarine system, 
the Pearl River Estuary, China J. Geophys. Res., 114, G03013, https://doi.org/10.1029/2008JG000905, 2009.

Gupta, G. V. M., Thottathil, S. D., Balachandran, K. K., Madhu, N. V., Madeswaran, P., and Nair, S.: $\mathrm{CO}_{2}$ supersaturation and net heterotrophy in a tropical estuary (Cochin, India): influence of anthropogenic effect, Ecosystems, 12, 1145-1157, https://doi.org/10.1007/s10021-009-9280-2, 2009.

Heip, C. H. R., Goosen, N. K., Herman, P. M. J., Kromkamp, J., Middelburg, J. J., and Soetaert, K.: Production and consumption of biological particles in temperate tidal estuaries, Oceanogr. Mar. Biol. Annu. Rev., 33, 1-149, 1995.

Hopkinson, C. S., Fry, B., and Nolin, A.: Stoichiometry of dissolved organic matter dynamics on the continental shelf of the Northeastern USA, Cont. Shelf Res., 17, 473-489, https://doi.org/10.1016/S0278-4343(96)00046-5, 1997.

Huang T.-H., Fu Y.-H., Pan P.-Y., and Arthur Chen, C.-T.: Fluvial carbon fluxes in tropical rivers, Curr. Opin. Env. Sust., 4, 162169, https://doi.org/10.1016/j.cosust.2012.02.004, 2012.

Ittekkot, V.: Global trends in the nature of organic matter in river suspensions, Nature, 332, 436-438, 1988.

Ittekkot, V. and Laane, R. W. P. M.: Fate of riverine particulate organic matter, in: Biogeochemistry of major world rivers, edited by: Degens, E. T., Kemp, S., and Richey, J. E., Chichester, Wiley, 233-243, 1991.

Jennerjahn, T. and Ittekkot, C. V.: Organic matter in sediments in the mangrove areas and adjacent continental margins of Brazil: I. Amino acids and hexosamines, Oceanol. Acta, 20, 359-369, 1997.

Jin, H., Yoon, T. K., Begum, M. S., Lee, E. J., Oh, N. H., Kang, N., and Park, J. H.: Longitudinal discontinuities in riverine greenhouse gas dynamics generated by dams and urban wastewater, Biogeosciences, 15, 6349-6369, https://doi.org/10.5194/bg-156349-2018, 2018.

Katsoyiannis, A. and Samara, C.: Ecotoxicological evaluation of the wastewater treatment process of the sewage treatment plant of Thessaloniki, Greece, J. Hazard. Mater., 141, 614-621, https://doi.org/10.1016/j.jhazmat.2006.07.038, 2006.

Katsoyiannis A. and Samara C.: The Fate of Dissolved Organic Carbon (DOC) in the wastewater treatment process and its importance in the removal of wastewater contaminants, Environ. Sci. Pollut. Res., 14, 284-292, https://doi.org/10.1065/espr2006.05.302, 2007.

Khan, R. A.: The pollution problem of Hooghly estuarine system; Estuarine Ecosystem Series, Zoological survey of India, Part 2, 497-542, 1995.

Kohn, M. J.: Carbon isotope compositions of terrestrial $\mathrm{C}_{3}$ plants as indicators of (paleo) ecology and (paleo) climate, P. Natl. Acad. Sci. USA, 107, 19691-19695, 2010.

Kristensen, E. and Alongi, D. M.: Control by fiddler crabs (Ucavocans) and plant roots (Avicennia marina) on carbon, iron, and sulphur biogeochemistry in mangrove sediment, Limnol. Oceanogr., 51, 1557-1571, https://doi.org/10.4319/lo.2006.51.4.1557, 2006.

Kristensen, E. and Suraswadi, P.: Carbon, nitrogen and phosphorus dynamics in creek water of a Southeast Asian mangrove forest, Hydrobiologia, 474, 197-211, 2002.

Le Quéré, C., Andrew, R. M., Canadell, J. G., Sitch, S., Korsbakken, J. I., Peters, G. P., Manning, A. C., Boden, T. A., Tans, P. P., Houghton, R. A., Keeling, R. F., Alin, S., Andrews, O. D.,
Anthoni, P., Barbero, L., Bopp, L., Chevallier, F., Chini, L. P., Ciais, P., Currie, K., Delire, C., Doney, S. C., Friedlingstein, P., Gkritzalis, T., Harris, I., Hauck, J., Haverd, V., Hoppema, M., Klein Goldewijk, K., Jain, A. K., Kato, E., Körtzinger, A., Landschützer, P., Lefèvre, N., Lenton, A., Lienert, S., Lombardozzi, D., Melton, J. R., Metzl, N., Millero, F., Monteiro, P. M. S., Munro, D. R., Nabel, J. E. M. S., Nakaoka, S.-I., O’Brien, K., Olsen, A., Omar, A. M., Ono, T., Pierrot, D., Poulter, B., Rödenbeck, C., Salisbury, J., Schuster, U., Schwinger, J., Séférian, R., Skjelvan, I., Stocker, B. D., Sutton, A. J., Takahashi, T., Tian, H., Tilbrook, B., van der Laan-Luijkx, I. T., van der Werf, G. R., Viovy, N., Walker, A. P., Wiltshire, A. J., and Zaehle, S.: Global Carbon Budget 2016, Earth Syst. Sci. Data, 8, 605-649, https://doi.org/10.5194/essd-8-605-2016, 2016.

Linto N., Barnes, J., Ramachandran, R., Divia, J., Ramachandran, P., and Upstill-Goddard, R. C.: Carbon dioxide and methane emissions from mangrove-associated waters of the Andaman Islands, Bay of Bengal, Estuar. Coast., 37, 381-398, https://doi.org/10.1007/s12237-013-9674-4, 2014.

Liss, P. S. and Merlivat, L.: Air sea gas exchange rates: introduction and synthesis, in: The Role of Air Sea Exchange in Geochemical Cycling, edited by: Buat-Menard, P., Hingham, M. A, and Reidel, D., 113-129, 1986.

Maher, D., Santos, I., Golsby-Smith, L., Gleeson, J., and Eyre, B.: Groundwater-derived dissolved inorganic and organic carbon exports from a mangrove tidal creek: The missing mangrove carbon sink?, Limnol. Oceanogr., 58, 475-488, https://doi.org/10.4319/lo.2013.58.2.0475, 2013.

Marwick, T. R., Tamooh, F., Teodoru, C.R., Borges, A.V., Darchambeau, F., and Bouillon, S.: The age of river-transported carbon: A global perspective, Global Biogeochem. Cy., 29, 122-137, https://doi.org/10.1002/2014GB004911, 2015.

Millero, F. J.: Chemical Oceanography, 4th edn., CRC press, Taylor and Francis Group, 2013.

Miyajima T., Tsuboi Y., Tanaka Y., and Koike, I.: Export of inorganic carbon from two Southeast Asian mangrove forests to adjacent estuaries as estimated by the stable isotope composition of dissolved inorganic carbon, J. Geophys. Res., 114, G01024, https://doi.org/10.1029/2008JG000861, 2009.

Mook, W. G. and Tan, T. C.: Stable carbon isotopes in rivers and estuaries, in: Biogeochemistry of Major World Rivers, SCOPE, edited by: Degens, E. T., Kempe, S., and Richey, J. E., John Wiley and Sons Ltd., 245-264, 1991.

Moran, M. A., Sheldon Jr., W. M., and Sheldon, J. E.: Biodegradation of riverine dissolved organic carbon in five estuaries of the south United States, Estuaries, 22, 55-64, 1999.

Mukhopadhyay, S. K., Biswas, H., De, T. K., Sen, S., and Jana, T. K.: Seasonal effects on the air-water carbon dioxide exchange in the Hooghly estuary, NE coast of Bay of Bengal, India, J. Environ. Monit., 36, 629-638, https://doi.org/10.1039/b201614a, 2002.

Mukhopadhyay, S. K., Biswas, H., De, T. K., and Jana, T. K.: Fluxes of nutrients from the tropical river Hooghly at the land-ocean boundary of Sundarbans, NE coast of Bay of Bengal, India, J. Marine Syst., 62, 9-21, https://doi.org/10.1016/j.jmarsys.2006.03.004, 2006.

Ray, R., Ganguly, D., Chowdhury, C., Dey, M., Das, S., Dutta, M. K., Mandal, S. K., Majumder, N., De, T. K., Mukhopadhyay, S. K., and Jana, T. K.: Carbon sequestration and annual increase of 
carbon stock in a mangrove forest, Atmos. Environ., 45, 50165024, https://doi.org/10.1016/j.atmosenv.2011.04.074, 2011.

Ray, R., Rixen, T., Baum, A., Malik, A., Gleixner, G., and Jana, T. K.: Distribution, sources and biogeochemistry of organic matter in a mangrove dominated estuarine system (Indian Sundarbans) during the pre-monsoon, Estuar. Coast. Shelf Sci. 167, 404-413, https://doi.org/10.1016/j.ecss.2015.10.017, 2015.

Ray, R., Baum, A., Rixen, T., Gleixner, G., and Jana, T. K.: Exportation of dissolved (inorganic and organic) and particulate carbon from mangroves and its implication to the carbon budget in the Indian Sundarbans, Sci. Total Environ., 621, 535-547, https://doi.org/10.1016/j.scitotenv.2017.11.225, 2018.

Raymond, P. A. and Bauer, J. E.: DOC cycling in a temperate estuary: a mass balance approach using natural ${ }^{14} \mathrm{C}$ and ${ }^{13} \mathrm{C}$, Limnol. Oceanogr., 46, 655-667, https://doi.org/10.4319/1o.2001.46.3.0655, 2001.

Raymond, P. A. and Cole, J. J.: Gas exchange in rivers and estuaries: Choosing a gas transfer velocity, Estuaries, 24, 312-317, https://doi.org/10.2307/1352954, 2001.

Reay, W. G., Gallagher, D., and Simmons, G. M.: Sediment water column nutrient exchanges in Southern Chesapeake Bay near shore environments, Virginia Water Resources Research Centre, Bulletin - 181b, 1995.

Regnier, P., Friedlingstein, P., Ciais, P., Mackenzie, F. T., Gruber, N., Janssens, I. A., Laruelle, G. G., Lauerwald, R., Luyssaert, S., Andersson, A. J., Arndt, S., Arnosti, C., Borges, A. V., Dale, A. W., Gallego-Sala, A., Godderis, Y., Goossens, N., Hartmann, J., Heinze, C., Ilyina, T., Joos, F., LaRowe, D. E., Leifeld, J., Meysman, F. J. R., Munhoven, G., Raymond, P. A., Spahni, R., Suntharalingam, P., and Thullner, M.: Anthropogenic perturbation of the carbon fluxes from land to ocean, Nat. Geosci., 6, 597-607, https://doi.org/10.1038/ngeo1830, 2013.

Rosentreter, J. A., Maher, D. T., Erler, D. V., Murray, R., and Eyre, B. D.: Seasonal and temporal $\mathrm{CO}_{2}$ dynamics in three tropical mangrove creeks - A revision of global mangrove $\mathrm{CO}_{2}$ emissions, Geochim. Cosmochim. Ac., 222, 729-745, https://doi.org/10.1016/j.gca.2017.11.026, 2018.

Rudra, K.: Changing river courses in the western part of the ganga-Brahmaputra delta, Geomorphology, 227, 87-100, https://doi.org/10.1016/j.geomorph.2014.05.013, 2014.

Sadhuram, Y., Sarma, V. V., Ramana Murthy, T. V., and Prabhakara Rao, B.: Seasonal variability of physicochemical characteristics of the Haldia channel of Hooghly estuary, Indian J. Earth Syst. Sci., 114, 37-49, https://doi.org/10.1007/BF02702007, 2005.

Samanta, S. and Dalai, T. K.: Massive production of heavy metals in the Ganga (Hooghly) River Estuary, India: global importance of solute-particle interaction and enhanced metal fluxes to the oceans, Geochim. Cosmochim. Ac., 228, 243-258, https://doi.org/10.1016/j.gca.2018.03.002, 2018.

Samanta, S., Dalai, T. K., Pattanaik, J. K., Rai, S. K., and Mazumdar, A.: Dissolved inorganic carbon (DIC) and its $\delta^{13} \mathrm{C}$ in the Ganga (Hooghly) River estuary, India: Evidence of DIC generation via organic carbon degradation and carbonate dissolution, Geochim. Cosmochim. Ac., 165, 226-248, https://doi.org/10.1016/j.gca.2015.05.040, 2015.

Sarkar, S. K., Mondal, P., Ok, Y. S., and Rinklebe, J.: Trace metal in surface sediments of the Hooghly (Ganges) estuary: distribution and contamination risk assessment, Environ. Geochem.
Health, 39, 1245-1258, https://doi.org/10.1007/s10653-0179952-3, 2017.

Sarma, V. V. S. S., Kumar, M. D., and Manerikar, M.: Emission of carbon dioxide from a tropical estuarine system, Goa, Indian Geophys. Res. Lett., 28, 1239-1242, https://doi.org/10.1029/2000GL006114, 2001.

Sarma, V. V. S. S., Viswanadham, R., Rao, G. D., Prasad, V. R., Kumar, B. S. K., Naidu, S. A., Kumar, N. A., Rao, D. B., Sridevi, T., Krishna, M. S., Reddy, N. P. C., Sadhuram, Y., and Murty, T. V. R.: Carbon dioxide emissions from Indian monsoonal Estuaries, Geophys. Res. Lett., 39, L03602, https://doi.org/10.1029/2011GL050709, 2012.

Sarma, V. V. S. S., Krishna, M. S., Prasad, V. R., Kumar, B. S. K., Naidu, S. A., Rao, G. D., Viswanadham, R., Sridevi, T., Kumar, P. P., and Reddy, N. P. C.: Sources and transformation of particulate organic matter in the Indian monsoonal estuaries during discharge period, J. Geophys. Res.-Biogeo., 119, 2095-2111, https://doi.org/10.1029/2011GL050709, 2014.

Seidl, M., Servais, P., and Mouchel, J. M.: Organic matter transport and degradation in the river Seine (France) after a combined sewer overflow, Water Res., 32, 3569-3580, https://doi.org/10.1016/S0043-1354(98)00169-9, 1998.

Servais, P., Billen, G., and Hascoet, M. C.: Determination of the biodegradable fraction of dissolved organic matter in waters, Water Res., 21445-21450, https://doi.org/10.1016/00431354(87)90192-8, 1987.

Singh, G., Ramanathan, A. L., Santra, S. C., and Rajan, R. K.: Tidal control on the nutrient variability in Sundarban mangrove ecosystem, J. Appl. Geochem., 18, 495-503, 2016.

Sippo, J. Z., Maher, D. T., Tait, D. R., Holloway, C., and Santos, I. R.: Are mangroves drivers or buffers of coastal acidification? Insights from alkalinity and dissolved inorganic carbon export estimates across a latitudinal transect, Global Biogeochem. Cy., 30, 753-766. https://doi.org/10.1002/2015GB005324, 2016.

Somayajulu B. L. K., Rengarajan R., and Jani R. A.: Geochemical cycling in the Hooghly estuary, Indian Mar. Chem., 79, 171-183, https://doi.org/10.1016/S0304-4203(02)00062-2, 2002.

Smith, B. N. and Epstein, S.: Two categories of ${ }^{13} \mathrm{C} /{ }^{12} \mathrm{C}$ ratios for higher plants, Plant Physiol., 47, 380-384, https://doi.org/10.1104/pp.47.3.380, 1971.

Tait, D. R., Maher, D. T., Macklin, P. A., and Santos, I. R.: Mangrove pore water exchange across a latitudinal gradient, Geophys. Res. Lett., 43, 3334-3341, https://doi.org/10.1002/2016GL068289, 2016.

Wanninkhof, R.: Relationship between wind speed and gas exchange over the ocean, J. Geophys. Res., 97, 7373-7382, https://doi.org/10.1029/92JC00188, 1992.

Weiss, R. F.: The solubility of nitrogen, oxygen and argon in water and seawater, Deep-Sea Res. Oceanogr. Abstracts, 17, 721-735, https://doi.org/10.1016/0011-7471(70)90037-9, 1970.

Zhai, W. D., Dai, M. H., Cai, W. J., Wang, Y. C., and Wang, Z. H.: High partial pressure of $\mathrm{CO}_{2}$ and its maintaining mechanism in a subtropical estuary: The Pearl River estuary, China, Mar. Chem., 93, 21-32, https://doi.org/10.1016/j.marchem.2004.07.003, 2005.

Zhai, W., Dai, M., and Guo, X.: Carbonate system and $\mathrm{CO}_{2}$ degassing fluxes in the inner estuary of Changjiang (Yangtze) River, China, Mar. Chem., 107, 342-356, https://doi.org/10.1016/j.marchem.2007.02.011, 2007. 